\title{
Sulfur deposition changes under sulfate geoengineering conditions: quasi-biennial oscillation effects on the transport and lifetime of stratospheric aerosols
}

\author{
Daniele Visioni $^{1,2}$, Giovanni Pitari ${ }^{1}$, Paolo Tuccella ${ }^{1,2}$, and Gabriele Curci ${ }^{1,2}$ \\ ${ }^{1}$ Department of Physical and Chemical Sciences, Università dell'Aquila, 67100 L'Aquila, Italy \\ ${ }^{2}$ CETEMPS, Università dell'Aquila, 67100 L'Aquila, Italy
}

Correspondence: Daniele Visioni (daniele.visioni@aquila.infn.it)

Received: 23 October 2017 - Discussion started: 1 November 2017

Revised: 18 January 2018 - Accepted: 25 January 2018 - Published: 27 February 2018

\begin{abstract}
Sustained injection of sulfur dioxide $\left(\mathrm{SO}_{2}\right)$ in the tropical lower stratosphere has been proposed as a climate engineering technique for the coming decades. Among several possible environmental side effects, the increase in sulfur deposition deserves additional investigation. In this study we present results from a composition-climate coupled model (University of L'Aquila Composition-Chemistry Model, ULAQ-CCM) and a chemistry-transport model (Goddard Earth Observing System Chemistry-Transport Model, GEOS-Chem), assuming a sustained lower-stratospheric equatorial injection of $8 \mathrm{Tg} \mathrm{SO}_{2} \mathrm{yr}^{-1}$. Total $\mathrm{S}$ deposition is found to globally increase by $5.2 \%$ when sulfate geoengineering is deployed, with a clear interhemispheric asymmetry $(+3.8$ and $+10.3 \%$ in the Northern Hemisphere $(\mathrm{NH})$ and the Southern Hemisphere (SH), due to +2.2 and $+1.8 \mathrm{Tg} \mathrm{Syr}^{-1}$, respectively). The two models show good consistency, both globally and on a regional scale under background and geoengineering conditions, except for Sdeposition changes over Africa and the Arctic. The consistency exists with regard to time-averaged values but also with regard to monthly and interannual deposition changes. The latter is driven essentially by the variability in stratospheric large-scale transport associated with the quasi-biennial oscillation (QBO). Using an externally nudged QBO, it is shown how a zonal wind $\mathrm{E}$ shear favors aerosol confinement in the tropical pipe and a significant increase in their effective radius ( $+13 \%$ with respect to $\mathrm{W}$ shear conditions). The net result is an increase in the downward cross-tropopause $\mathrm{S}$ flux over the tropics with dominant $\mathrm{E}$ shear conditions with re-
\end{abstract}

spect to $\mathrm{W}$ shear periods $\left(+0.61 \mathrm{Tg} \mathrm{S} \mathrm{yr}^{-1},+42 \%\right.$, mostly due to enhanced aerosol gravitational settling) and a decrease over the extratropics $\left(-0.86 \mathrm{Tg} \mathrm{S} \mathrm{yr}^{-1},-35 \%\right.$, mostly due to decreased large-scale stratosphere-troposphere exchange of geoengineering sulfate). This translates into S-deposition changes that are significantly different under opposite QBO wind shears, with an E-W anomaly of +0.32 in the tropics and $-0.67 \mathrm{Tg} \mathrm{S} \mathrm{yr}^{-1}$ in the extratropics. Most online QBO schemes predict a significant change in the zonal wind periodicity, up to a blocked $\mathrm{E}$ shear condition for large enough injections, so that our results indicate an upper limit for the tropical increase in $S$ deposition of $16.5 \%$ relative to average conditions of unperturbed QBO periodicity and a correspondent extratropical S deposition decrease of $16 \%$.

\section{Introduction}

The evidence of the increase in greenhouse gases (GHGs) due to anthropogenic emissions and the subsequent increase in surface temperatures has started discussions on the possibility of temporarily altering the climate to alleviate some of the consequences. Injecting sulfur dioxide $\left(\mathrm{SO}_{2}\right)$ in the tropical lower stratosphere in order to simulate the cooling effects of explosive volcanic eruptions is one of the techniques proposed for this purpose. In the case of explosive eruptions, the cooling effect comes from the increase in stratospheric aerosol optical depth (by 1 order of magnitude or more) due to the nucleation and condensation of 
$\mathrm{H}_{2} \mathrm{SO}_{4}$ formed through $\mathrm{OH}$ oxidation of the initial volcanic $\mathrm{SO}_{2}$ cloud injected into the stratosphere (McCormick and Veiga, 1992; Lambert et al., 1993; Long and Stowe, 1994). These gas-particle microphysical processes, coupled to additional aerosol growth due to coagulation, produce an optically active cloud which is highly reflective in the visible and UV, causing a substantial decrease in solar radiation reaching the Earth surface and, subsequently, a global surface cooling. This same effect could in principle be achieved by deliberately injecting $\mathrm{SO}_{2}$ into the stratosphere (Budyko, 1974; Crutzen, 2006; Niemeier and Tilmes, 2017). However, other direct and indirect effects have been observed together with the surface cooling, such as a $2-3 \mathrm{~K}$ warming of the tropical lower stratosphere after the Pinatubo eruption (Labitzke and McCormick, 1992) and a decrease of about $20 \mathrm{DU}$ in the tropical ozone column in the 16-28 km layer during October-November 1991 (Grant et al., 1992).

Many studies have already been carried out regarding possible side effects of sulfate geoengineering (SG; Visioni et al., 2017a), mainly under the Geoengineering Model Intercomparison Project (GeoMIP), where several different model experiments regarding SG have been devised (Kravitz et al., 2011, 2012; Robock et al., 2011), considering a background anthropogenic forcing profile corresponding to Representative Concentration Pathway 4.5 (RCP4.5; Taylor et al., 2012). In particular, the G4 experiment described in (Kravitz et al., 2011) aims to simulate a constant injection of a certain number of $\mathrm{Tg} \mathrm{S} \mathrm{yr}^{-1}$ into the lower stratosphere. Regarding possible effects on ozone, an enhancement of stratospheric ozone destruction has been reported in Tilmes et al. (2008), with a subsequent significant increase in surface UV-B in the polar regions (Tilmes et al., 2012) together with a general decrease in upper-tropospheric ozone due to perturbed stratospheretroposphere fluxes (Xia et al., 2017). An increase in the concentration and lifetime of methane has also been found (Visioni et al., 2017b) for the same injection magnitude of this study. Coordinated modeling experiments, such as those under the umbrella of the ongoing Stratosphere-troposphere Processes And their Role in Climate - Chemistry-Climate Models Intercomparison (SPARC-CCMI), have been suggested by Tilmes et al. (2015), through the use of a prescribed field of surface area density of stratospheric sulfate aerosols, in order to bound model uncertainties pointed out in Pitari et al. (2014).

Dynamical changes and perturbations in the transport of stratospheric tracer species, due to the local stratospheric heating and to the cooling of the surface have already been studied regarding volcanic sulfate particles, as documented in a fairly extensive literature (e.g., Pitari, 1993; Kirchner et al., 1999; Soden et al., 2002). The increase in aerosol heating rates in the tropical lower stratosphere affects the stratospheric mean meridional circulation, while at the same time the changing atmospheric stability (due to the surface cooling) alters the planetary wave propagation in the mid- to high latitude lower stratosphere. Regarding the possible side ef- fects of SG, a study by Aquila et al. (2014) analyzed the effects on the quasi-biennial oscillation (QBO), a periodic oscillation between zonally symmetric easterly and westerly winds that may significantly impact the whole stratospheric dynamics, as for example the strength of the polar vortex (Holton and Tan, 1980) and the transport of stratospheric aerosols and trace gases from the tropics to mid- to high latitudes (Trepte and Hitchman, 1992). In the aforementioned study by Aquila et al. (2014), further confirmed by Niemeier and Timmreck (2015), a prolonged QBO westerly phase in the lower stratosphere was found as a consequence of $\mathrm{SG}$, with larger $\mathrm{SO}_{2}$ injections producing increasing heating rates and finally larger QBO perturbations. While Aquila et al. (2014) used a 5 and $10 \mathrm{Tg} \mathrm{SO}_{2} \mathrm{yr}^{-1}$ injection at two different altitudes (15-26 and 22.5-25 km), Niemeier and Timmreck (2015) reached injections of up to $200 \mathrm{Tg} \mathrm{SO}_{2} \mathrm{yr}^{-1}$.

The lifetime of tropical aerosols in the lower stratosphere may change under different QBO conditions, since the latter controls the isolation of the tropical pipe, thus reducing the amount of large-scale transport in the downwelling branch of the Brewer-Dobson circulation. In particular, the stratospheric aerosol lifetime during volcanic eruptions taking place under a QBO easterly shear of the equatorial winds (e.g., Nevado del Ruiz, Pinatubo) has been shown to be longer with respect to the lifetime for eruptions under a QBO westerly wind shear (e.g., Agung, El Chichón; Pitari et al., 2016b, a).

Moreover, a question that often arises regarding SG, is how much the injection of sulfate would affect its deposition, and whether this deposition would take the form of acid rain by considering which portion of deposition is wet and which is dry. Early results on this problem have been obtained by Kravitz et al. (2009), who used a simulated $5 \mathrm{Tg} \mathrm{SO}_{2} \mathrm{yr}^{-1}$ injection and found that the additional sulfate deposition (in their studies considered as if all deposition was in the form of sulfuric acid) would not be enough to have any impact on ecosystem throughout the globe (see also the available addendum correction, Kravitz et al., 2010, that does not change the overall conclusions of the previous paper, as the authors state). In the present work, we plan to expand on their findings further, by including the QBO effects on the stratospheric circulation, to see if these dynamical oscillations may produce significant changes in $\mathrm{S}$ deposition.

This paper is organized into three successive parts, plus the conclusions. In the first part we describe the two models used in the experiment (University of L'Aquila CompositionChemistry Model, ULAQ-CCM, and Goddard Earth Observing System Chemistry-Transport Model, GEOS-Chem). In the second part we analyze how the lifetime of geoengineering sulfate aerosols can be correlated to stratospheric circulation changes and different QBO phases, in order to better understand the mechanisms regulating the sulfur deposition time variability. The latter will be shown to be mostly produced by QBO-driven stratospheric circulation changes and induced modifications of the aerosol size dis- 
Table 1. Summary of model features in this experiment. Aerosol-related quantities are averaged over the years 2000-2005 in GEOS-Chem and the ULAQ-CCM reference and over the years 2030-2039 for ULAQ-CCM Base (RCP4.5) and G4 simulations. NH: Northern Hemisphere; SH: Southern Hemisphere; MERRA: Modern-Era Retrospective analysis for Research and Applications; DMS: dimethyl sulfide.

\begin{tabular}{|c|c|c|c|}
\hline Model & GEOS-Chem & \multicolumn{2}{|c|}{ ULAQ-CCM } \\
\hline Years of simulation & $1998-2005$ & 1990-2010 & $2020-2050$ \\
\hline Type of simulation & Base + G4 & Reference & Base $(\mathrm{RCP} 4.5)+\mathrm{G} 4$ \\
\hline Ensemble size & $1+1$ & 2 & $1+2$ \\
\hline $\begin{array}{l}\text { Horizontal and vertical } \\
\text { resolution }\end{array}$ & $\begin{array}{l}4^{\circ} \times 5^{\circ}, \mathrm{L} 72 \\
\text { Hybrid pressure-sigma } \\
\text { top: } 0.01 \mathrm{hPa}\end{array}$ & \multicolumn{2}{|c|}{$\begin{array}{l}5^{\circ} \times 6^{\circ}, \mathrm{L} 126 \\
\text { Log-pressure } \\
\text { top: } 0.04 \mathrm{hPa}\end{array}$} \\
\hline Chemistry & Online (strat. + trop.) & \multicolumn{2}{|c|}{ Online (strat. + trop.) } \\
\hline Dynamics & Assimilated $^{1}$ & $\begin{array}{l}\text { Calculated }{ }^{2} \\
\text { Nudged (from }\end{array}$ & $\begin{array}{l}\text { Calculated }{ }^{3} \\
\text { Nudged (iteration of }\end{array}$ \\
\hline QBO & $\begin{array}{l}\text { Online (with } \\
\text { assimilated winds) }\end{array}$ & $\begin{array}{l}\text { equatorial wind } \\
\text { observations) }\end{array}$ & $\begin{array}{l}\text { observed cycles of } \\
\text { equatorial winds) }\end{array}$ \\
\hline $\begin{array}{l}\text { Tropical } w *\left(\mathrm{~mm} \mathrm{~s}^{-1}\right) \\
(30-70 \mathrm{hPa})\left(20^{\circ} \mathrm{S}-20^{\circ} \mathrm{N}\right)\end{array}$ & +0.24 & +0.25 & $\begin{array}{l}+0.25 \text { (Base) } \\
+0.26(\mathrm{G} 4)\end{array}$ \\
\hline $\begin{array}{l}\text { Altitude of equatorial injection } \\
\text { of } \mathrm{SO}_{2} \text { in experiment } \mathrm{G} 4\end{array}$ & $\begin{array}{l}18-25 \mathrm{~km} \\
\text { (uniform distribution) }\end{array}$ & - & $\begin{array}{l}18-25 \mathrm{~km} \\
\text { (Gaussian distribution) }\end{array}$ \\
\hline $\begin{array}{l}\text { Stratospheric sulfate aerosols } \\
(50 \mathrm{hPa} \text { equatorial effective } \\
\text { radius }(\mu \mathrm{m}))\end{array}$ & $\begin{array}{l}\text { Bulk }^{4} \\
0.19 \text { (Base) } \\
0.62 \text { (G4) }\end{array}$ & $\begin{array}{l}\text { Calculated size distr. } \\
0.19\end{array}$ & $\begin{array}{l}\text { Calculated size distr. }^{5} \\
0.19 \text { (Base) } \\
0.78 \text { (G4) }\end{array}$ \\
\hline $\begin{array}{l}\text { Aerosol settling velocity }\left(\mathrm{mm} \mathrm{s}^{-1}\right) \\
(30-70 \mathrm{hPa})\left(20^{\circ} \mathrm{S}-20^{\circ} \mathrm{N}\right)\end{array}$ & $\begin{array}{l}-0.09 \text { (Base) } \\
-0.34(\mathrm{G} 4)\end{array}$ & -0.09 & $\begin{array}{l}-0.09 \text { (Base) } \\
-0.38(\mathrm{G} 4)\end{array}$ \\
\hline $\begin{array}{l}\text { Stratospheric } \mathrm{SO}_{4} \text { flux out of } \\
\text { the tropical pipe }\left(\mathrm{Tg} \mathrm{S} \mathrm{yr}^{-1}\right)\end{array}$ & $\begin{array}{l}0.05 \text { (Base) } \\
2.31 \text { (G4-Base) }\end{array}$ & 0.04 & $\begin{array}{l}0.04 \text { (Base) } \\
2.55 \text { (G4-Base) }\end{array}$ \\
\hline $\begin{array}{l}\text { Stratospheric lifetime of } \\
\mathrm{SO}_{4} \text { (months) }\end{array}$ & $\begin{array}{l}13.7 \text { (Base) } \\
13.5 \text { (G4-Base) }\end{array}$ & 12.4 & $\begin{array}{l}12.6 \text { (Base) } \\
12.1 \text { (G4-Base) }\end{array}$ \\
\hline $\begin{array}{l}\text { Stratospheric lifetime of } \\
\mathrm{SO}_{2} \text { (days) }\end{array}$ & $\begin{array}{l}27.9 \text { (Base) } \\
29.0 \text { (G4-Base) }\end{array}$ & 27.5 & $\begin{array}{l}23.4 \text { (Base) } \\
32.1 \text { (G4-Base) }\end{array}$ \\
\hline $\begin{array}{l}\text { S-emission fluxes } \\
\left(\mathrm{Tg} \mathrm{S} \mathrm{yr}^{-1}\right) \text { (Base) }\end{array}$ & $\begin{array}{l}60\left(\mathrm{SO}_{x}\right) \\
18(\mathrm{DMS}) \\
76.8(\text { total })\end{array}$ & $\begin{array}{l}67\left(\mathrm{SO}_{x}\right) \\
28(\mathrm{DMS}) \\
93.3(\text { total })\end{array}$ & $\begin{array}{l}50\left(\mathrm{SO}_{x}\right) \\
28(\mathrm{DMS}) \\
76.2 \text { (total) }\end{array}$ \\
\hline $\begin{array}{l}\text { S-deposition fluxes } \\
\left(\mathrm{Tg} \mathrm{S} \mathrm{yr}^{-1}\right) \text { (Base) }\end{array}$ & $\begin{array}{l}44.1 \text { (land) } \\
32.7 \text { (ocean) } \\
4.0(\text { total })(5.2 \%)\end{array}$ & $\begin{array}{l}54.0 \text { (land) } \\
39.3 \text { (ocean) }\end{array}$ & $\begin{array}{l}38.0 \text { (land) } \\
38.2 \text { (ocean) } \\
4.0(\text { total })(5.2 \%)\end{array}$ \\
\hline $\begin{array}{l}\text { S-deposition flux changes } \\
(\mathrm{Tg} \mathrm{S} \mathrm{yr}-1) \text { (G4-Base) }\end{array}$ & $\begin{array}{l}(3.2 \% \mathrm{NH} 10.6 \% \mathrm{SH}) \\
1.5 \text { (land) } \\
2.5 \text { (ocean) }\end{array}$ & - & $\begin{array}{l}(4.4 \% \mathrm{NH} 10.0 \% \mathrm{SH}) \\
1.8 \text { (land) } \\
2.2 \text { (ocean) }\end{array}$ \\
\hline
\end{tabular}

\footnotetext{
${ }^{1}$ Thirty-year reanalysis (MERRA) at native horizontal resolution of $0.5^{\circ} \times 0.666^{\circ} .{ }^{2}$ Sea surface temperatures from observations; calculated land temperatures. ${ }^{3}$ Surface temperatures from CCSM-CAM4, separately for RCP4.5 and G4 (Visioni et al., $2017 \mathrm{~b}$ ). ${ }^{4}$ Effective radius calculated from sulfate volume density, using the fit of Grainger et al. (1995). ${ }^{5}$ Sectional approach (Pitari et al., 2002, 2014).
}

tribution. In the third part, we first evaluate the model results of baseline $\mathrm{S}$ deposition with independent multi-model simulations and available surface observations. After that, we quantify the time-averaged continental-scale deposition changes produced by SG, pointing out the role of different QBO wind shears in regulating the latitudinal distribution of S-deposition changes. We finally highlight a possible upperlimit latitudinal modification of the time-averaged S deposi- 
tion in the case SG aerosol heating rates are allowed to feedback on the QBO itself.

\section{Description of models}

In this section, we present a compact description of the two models used in this experiment.The choice to use a chemistry-climate model (CCM) and a chemical transport model (CTM) stems from the need to account for changes in the stratospheric circulation, attributable to chemical and radiative interactions of geoengineering sulfate aerosols. The ULAQ-CCM was already tested in similar conditions both for large explosive volcanic eruptions (Pitari et al., 2016b, a) and sulfate geoengineering (Pitari et al., 2014; Visioni et al., 2017b). At the same time, we wanted to support the global CCM conclusions on sulfate deposition with the results of a "transport-robust" and widely tested community model such as GEOS-Chem, a CTM using observed meteorology from the Modern-Era Retrospective analysis for Research and Applications (MERRA).

We performed two sets of simulations with both models: an unperturbed (Base) case and a geoengineering perturbed (G4) case, with an injection of $8 \mathrm{Tg} \mathrm{SO}_{2} \mathrm{yr}^{-1}$ in the equatorial stratosphere (between 18 and $25 \mathrm{~km}$ of altitude), as described in the GeoMIP G4 experiment (Kravitz et al., 2011). The simulations were, however, performed during different time periods for ULAQ-CCM and GEOS-Chem. For the former, the simulated period is between 2020 and 2090, with analyses focusing on the 2030-2039 decade, with the Base and the G4 cases both taking place under the same background RCP4.5 scenario. For GEOS-Chem, on the other hand, the simulated period is between 1998 and 2005 (with 1998-1999 for spin-up) and the simulations use assimilated dynamics for those years, both in the unperturbed and geoengineering perturbed experiments and with the same sulfur injection amount as in ULAQ-CCM for the G4 case. A third simulation was carried out with ULAQ-CCM as a reference case during the historical period (1990-2010), in order to consistently evaluate model results on regional deposition against GEOS-Chem results, independent multi-model simulations and available surface observations.

A compact summary of model features in these numerical experiments is presented in Table 1, along with the most relevant aerosol-related quantities averaged over the years 2000-2005 in GEOS-Chem and the ULAQ-CCM reference case and over the years 2030-2039 for ULAQ-CCM Base (RCP4.5) and G4 simulations. The most important drivers of stratospheric sulfate aerosol formation, horizontal/vertical transport and removal are highly consistent in the two models, namely $\mathrm{SO}_{2}$ oxidation, tropical upwelling coupled to isentropic mixing out of the tropical pipe, tropospheric influx due to large-scale downwelling in the Brewer-Dobson lower branch and gravitational sedimentation. The same is also true of the calculated $\mathrm{SO}_{2}$ and $\mathrm{SO}_{4}$ lifetimes, with a somewhat longer lifetime of geoengineering stratospheric aerosols in GEOS-Chem with respect to ULAQ-CCM (i.e., 13.5 months versus 12.1 months) mostly attributable to a larger effective radius of aerosols particles in the latter model. The assumption of a uniform $\mathrm{SO}_{2}$ stratospheric injection in GEOS-Chem is also significant from this point of view, by keeping a larger fraction of geoengineering sulfate mass at higher altitudes over the tropical tropopause, with respect to ULAQ-CCM, which adopted a Gaussian distribution centered at $21.5 \mathrm{~km}$. Global budgets of sulfur emission and deposition fluxes at the ground surface are also consistent between the two models.

The sulfur budget in both models is summarized in Tables $2-4$, looking at integrated sulfur emission and deposition fluxes for baseline conditions over land, ocean and the entire globe, including a comparison with data presented in Vet et al. (2014) and Lamarque et al. (2013). Both models are consistent with observations and multi-model coupled data of sulfur emission and deposition fluxes reported in Vet et al. (2014), as well as with multi-model ensemble data reported in Lamarque et al. (2013) (see Table 2). Global DMS (dimethyl sulfide) emission in GEOS-Chem is lower than in ULAQ-CCM: these are in the lower and upper bounds of the variability shown in Lamarque et al. (2013). The global sulfur deposition is always somewhat smaller than the total $\mathrm{SO}_{x}+\mathrm{DMS}$ emission, due to the $87 \%$ yield of DMS oxidation in $\mathrm{SO}_{2}$, which finally produces sulfate (as discussed in Lamarque et al., 2013); the remaining part goes into MSA (methane sulfonate) aerosols, which are finally lost by wet deposition. The geoengineering $\mathrm{SO}_{2}$ injection adopted in this study $\left(8 \mathrm{Tg} \mathrm{SO}_{2} \mathrm{yr}^{-1}\right.$, i.e., $\left.4 \mathrm{Tg} \mathrm{S} \mathrm{yr}^{-1}\right)$ represents $5.1 \%$ globally of the baseline anthropogenic and natural sulfur emissions (see Table 3), and the resulting surface deposition represents $5.2 \%$ of the baseline deposition, with a significant interhemispheric asymmetry (3.8 and 10.3\% in the Northern Hemisphere $(\mathrm{NH})$ and the Southern Hemisphere (SH), respectively, as a model average; see Table 1). The latter is mostly due to the quasi-homogeneous tropospheric influx of sulfate formed in the stratosphere from a geoengineering equatorial $\mathrm{SO}_{2}$ injection and by the highly inhomogeneous amount of anthropogenic sulfur emissions in the boundary layer (mostly localized in the Northern Hemisphere).

One important difference between the GEOS-Chem simulations performed here and ULAQ-CCM is that the first adopts a bulk approach for stratospheric aerosols, whereas ULAQ-CCM predicts the aerosol size distribution online, with a more detailed calculation of the net sedimentation loss. The explicitly calculated effective radius (ULAQ-CCM) or that indirectly derived using the Grainger et al. (1995) method (GEOS-Chem) are both consistent with the Stratospheric Aerosol and Gas Experiment (SAGE) II derived estimates approximately 1 year after the Pinatubo eruption, with comparable integrated stratospheric sulfate mass (Pitari et al., 2014; Visioni et al., 2017b). The breakdown of global 
$\mathrm{SO}_{x}$ deposition fluxes, among $\mathrm{SO}_{2}$ and $\mathrm{SO}_{4}$ dry- and wetdeposition terms, is summarized in Table 4 for the two models, and a comparison is made with multi-model data presented in Lamarque et al. (2013). As expected, the deposition of geoengineering $\mathrm{SO}_{x}$ (G4-Base) is greatly attributable to $\mathrm{SO}_{4}$ wet deposition $\left(85.8 \%\right.$ ), with $11.5 \%$ due to $\mathrm{SO}_{x}$ dry deposition (model averages).

Both models have been fully described in the recent literature. For the sake of completeness, we report in the following two sub-sections some of the main model features, in particular those relevant for sulfur species and aerosols.

\subsection{ULAQ-CCM}

ULAQ-CCM has been described in its first version in Pitari et al. (2002) and later within the framework of SPARCCCMVal (Chemistry Climate Models Validation) and the ongoing SPARC-CCMI campaigns (Eyring et al., 2006; Morgenstern et al., 2010, 2017). Important model updates regarding horizontal and vertical resolution (now T21 with 126 log-pressure levels), species cross sections and SchumannRunge bands treatment and upgrades of the radiative transfer code were described and tested in Pitari et al. (2014). This radiative module, crucial for a good prediction of the sulfate aerosol interaction with shortwave solar and longwave planetary radiation has been tested for tropospheric aerosols in SPARC-AeroCom (Randles et al., 2013) and also for stratospheric aerosols after major volcanic eruptions (Pitari et al., 2016b). The shortwave radiative module uses a two-stream delta-Eddington approximation and operates online in the ULAQ-CCM. It is used for both photolysis rate calculations in ultra-violet (UV) to visible (VIS) wavelengths and also for solar heating rates and radiative forcing in UV-VIS and solar near-infrared (NIR) bands. In addition, a companion broadband, $k$-distribution longwave radiative module is used to compute radiative transfer and heating rates in the planetary infrared spectrum (Chou et al., 2001).

The skills of the model regarding upper-troposphere and lower-stratosphere (UTLS) dynamics have been evaluated in multi-model assessment both in the tropical region (Gettelman et al., 2010) and in the extratropics (Hegglin et al., 2010). Particularly important for the geoengineering study discussed in the present study are the effects on lowerstratospheric dynamics of the QBO and sea surface temperatures (SSTs). The ULAQ-CCM uses a nudged QBO extrapolated from an observed historical data series (Morgenstern et al., 2017). The treatment of surface temperatures, and their importance under a geoengineering scenario, has been discussed in Visioni et al. (2017b). ULAQ-CCM does not have a coupled ocean, but the simulation under a control scenario RCP4.5 and the geoengineering simulation G4 use different surface temperatures, which are externally calculated in a fully coupled atmosphere-ocean model (Community Climate System Model-Community Atmosphere Model v. 4.0 (CCSM-CAM4)).
For the $\mathrm{G} 4$ simulations, $\mathrm{SO}_{2}$ is injected at $0^{\circ}$ longitude on the equator, throughout the altitude range $18-25 \mathrm{~km}$ with a Gaussian distribution centered at $21.5 \mathrm{~km}$. Stratospheric $\mathrm{SO}_{2}$ oxidation by $\mathrm{OH}$ (calculated online in the full chemistry module) produces $\mathrm{SO}_{4}$. The resulting size distribution of supercooled $\mathrm{H}_{2} \mathrm{O}-\mathrm{H}_{2} \mathrm{SO}_{4}$ particles is calculated in an aerosol microphysics module with a sectional approach, starting from gas-particle interaction processes (homogeneous and heterogeneous nucleation, sulfuric acid condensation, water vapor growth) and then including aerosol coagulation, gravitational settling and evaporation in the upper stratosphere.

Aerosol optical thickness and single scattering albedo are calculated as a function of wavelength at all model grid points, with the online calculation of up or down diffuse radiation and absorption of solar near-infrared and planetary radiation. Aerosol modulated radiative fluxes may then explicitly impact species photolysis and heating rates of ozone and aerosols. The surface area density of sulfate aerosols is calculated interactively in the model starting from the calculated size distribution of these particles, as well as for polar stratospheric cloud particles, which are also treated with a sectional approach (explicit microphysics, particle transport, impact on stratospheric denitrification and dehydration) without imposing a thermodynamics equilibrium (Pitari et al., 2002; Butchart et al., 2010; Morgenstern et al., 2017). This allows an explicit full coupling of aerosol, chemistry and radiation modules in the ULAQ-CCM; for this reason the acronym CCM (in this specific case) is more appropriate for "composition-climate model" rather than "chemistryclimate model", which it usually stands for. Geoengineering sulfate aerosols (or those produced after major volcanic eruptions) may significantly perturb wavelength-dependent aerosol extinction, absorption and asymmetry parameter at all model grid points, thus allowing the online calculation of radiative flux perturbations, with consequent changes in $\mathrm{O}_{2}$ and $\mathrm{O}_{3}$ photolysis, $\mathrm{O}_{3}$ heating rates, and aerosol heating rates in the solar and planetary infrared ranges (Pitari et al., 2014, 2016b).

In the troposphere, the ULAQ-CCM includes the major aerosol families (sulfate, nitrate, organic and black carbon, soil dust, sea salt). The sulfate aerosol module starts from DMS and $\mathrm{SO}_{2}$ emissions (fossil fuel, biomass burning, nonexplosive volcanoes; Eyring et al., 2013; Lamarque et al., 2010) and includes $\mathrm{SO}_{x}$ chemistry with gas phase oxidation of DMS into $\mathrm{SO}_{2}$, via reactions with $\mathrm{OH}$ (daytime) and $\mathrm{NO}_{3}$ (nighttime), and gas phase and aqueous or ice $\mathrm{SO}_{2}$ oxidation (by $\mathrm{OH}, \mathrm{H}_{2} \mathrm{O}_{2}$ and $\mathrm{O}_{3}$, respectively) to produce $\mathrm{SO} 4$ (Feichter et al., 1996; Clegg and Abbatt, 2001). As in the stratosphere, gas-particle conversion allows the formation of aerosol particles, typically made of ammonium sulfate (in the boundary layer and lower and mid-troposphere) or supercooled $\mathrm{H}_{2} \mathrm{O}-\mathrm{H}_{2} \mathrm{SO}_{4}$ in the upper troposphere. The resulting size distribution is regulated by the microphysical processes cited above. The tropospheric and stratospheric $\mathrm{SO}_{x}$ budget in the ULAQ-CCM (for unperturbed background conditions) 
Table 2. Integrated sulfur emission and deposition fluxes for baseline conditions over land, ocean and the entire globe, for ULAQ-CCM and GEOS-Chem, compared to Vet et al. (2014) and Lamarque et al. (2013) values ( $\mathrm{Tg} \mathrm{S} \mathrm{yr}^{-1}$ ).

\begin{tabular}{lrrrrrr}
\hline & $\begin{array}{r}\text { GEOS-Chem } \\
(2000-2005)\end{array}$ & $\begin{array}{r}\text { ULAQ-CCM } \\
(2000-2005)\end{array}$ & $\begin{aligned} \text { Vet et al. (2014) } \\
(2001)\end{aligned}$ & $\begin{array}{r}\text { Lamarque et al. (2013) } \\
(2001)\end{array}$ & $\begin{array}{r}\text { ULAQ-CCM } \\
(2030-2039)\end{array}$ & $\begin{array}{r}\text { Lamarque et al. (2013) } \\
(2030 \text { RCP4.5) }\end{array}$ \\
\hline Land total emissions & 49.1 & 59.7 & 50.4 & 56 & 45.0 & 43 \\
Ocean total emissions & 28.9 & 35.3 & 40.6 & 33 & 34.6 & 35 \\
Total globe emissions & 78.0 & 95.0 & 91.0 & $49 \pm 13$ & 77.6 & 38.0 \\
Land total deposition & 44.1 & 54.0 & 40.2 & 43 & 38.2 & $76 \pm 6$ \\
Ocean total deposition & 32.7 & 39.3 & 44.6 & $87 \pm 17$ & 76.2 & 76 \\
Total globe deposition & 76.8 & 93.3 & 84.8 & & $76 \pm 16$ \\
\hline
\end{tabular}

Table 3. Breakdown of global sulfur emission fluxes $\left(\mathrm{Tg} \mathrm{S} \mathrm{yr}^{-1}\right)$.

\begin{tabular}{lrrrrr}
\hline & $\begin{array}{l}\text { GEOS-Chem } \\
(2000-2005)\end{array}$ & $\begin{array}{r}\text { ULAQ-CCM } \\
(2000-2005)\end{array}$ & $\begin{array}{r}\text { Lamarque et al. (2013) } \\
(2001)\end{array}$ & $\begin{array}{r}\text { ULAQ-CCM } \\
(2030-2039)\end{array}$ & $\begin{array}{r}\text { Lamarque et al. (2013) } \\
(2030 \text { RCP4.5) }\end{array}$ \\
\hline $\mathrm{SO}_{x}$ & 60 & 67 & 66 & 50 & 55 \\
$\mathrm{DMS}$ & 18 & 28 & 23 & 28 & 23 \\
Total Base & 78 & 95 & $89 \pm 14$ & 78 & $78 \pm 6$ \\
$\mathrm{SO}_{2}$ geoengineering & $4.0(5.1 \%)$ & - & - & $4.0(5.1 \%)$ & - \\
\hline
\end{tabular}

was first discussed in Pitari et al. (2002) and more recently in Pitari et al. (2016c), with a focus on the role of nonexplosive volcanic sulfur emissions. Surface mixing ratios of long-lived species and gridded emission fluxes of tropospheric ozone precursors $\left(\mathrm{NO}_{x}, \mathrm{CO}, \mathrm{VOCs}\right.$ - volatile organic compounds) and aerosols are all prescribed in the RCP4.5 baseline scenario, following the Eyring et al. (2013) recommendations for the CCMI intercomparison campaign; gridded data for short-lived species emissions were made available by Lamarque et al. (2010).

Dry deposition of gas species and aerosols is calculated in terms of a surface deposition velocity (Muller and Brasseur, 1995). Washout of soluble gases and aerosols is treated as a first-order loss rate, in terms of climatological monthly averaged precipitation rates; the vertical distribution is calculated as a function of climatological distributions of cumulonimbus and nimbostratus clouds (Muller and Brasseur, 1995; Pitari et al., 2002). The aerosol gravitational sedimentation is treated in a sectional approach, by calculating the appropriate settling velocity for a given particle composition and size.

\subsection{GEOS-Chem}

GEOS-Chem is a community global Eulerian chemistrytransport model originally described in Bey et al. (2001). Here we employ version v11-01 of the model (www. geos-chem.org). GEOS-Chem is driven by assimilated meteorological fields from the Goddard Earth Observation System (GEOS) of the NASA Global Modeling and Assimilation Office (GMAO). Here we use the 30-year MERRA provided at a native horizontal resolution of $0.5^{\circ} \times 0.666^{\circ}$ and degraded here to $4^{\circ} \times 5^{\circ}$ for GEOS-Chem simulations.
The number of hybrid pressure-sigma vertical levels is 72 up to $0.01 \mathrm{hPa}$ (ca. $80 \mathrm{~km}$ ), with spacing gradually increasing with height from $0.1 \mathrm{~km}$ near the surface to $2 \mathrm{~km}$ near the model top. Advection is calculated using the semiLagrangian scheme developed by Lin and Rood (1996), convective transport is calculated following Wu et al. (2007), and mixing in the planetary boundary layer is calculated using the nonlocal scheme implemented by Lin and McElroy (2010).

Anthropogenic emissions of $\mathrm{CO}, \mathrm{NO}_{x}$ and $\mathrm{SO}_{2}$ use the global EDGAR4.2 (Emission Database for Global Atmospheric Research) inventory (Lin and McElroy, 2010), complemented with regional inventories for the US, Canada, Mexico, Europe and East Asia (see http://acmg.seas.harvard. edu/geos/geos_chem_narrative.html for details). For $\mathrm{N}_{2} \mathrm{O}$, CFCs, HCFCs, OCS and other chlorine species a fixed global mixing ratio is specified at the model surface (Eastham et al., 2014), while bromine species emissions are described in Parrella et al. (2012). Eruptive and noneruptive volcanic $\mathrm{SO}_{2}$ emissions use the AeroCom database as implemented by Fisher et al. (2011).

The chemical mechanism of GEOS-Chem includes a detailed $\mathrm{HO}_{x}-\mathrm{NO}_{x}-\mathrm{VOC}-\mathrm{O}_{3}-\mathrm{BrO}_{x}$ tropospheric chemistry originally described by Bey et al. (2001) and updated to the most recent JPL/IUPAC (Jet Propulsion Laboratory/International Union of Pure and Applied Chemistry) recommendations. The stratospheric chemistry mechanism uses the Universal tropospheric-stratospheric Chemistry eXtension (UCX) developed by Eastham et al. (2014). The sulfate-nitrate-ammonium and carbonaceous aerosol chemistry was originally developed by Park et al. (2003) and Park et al. (2004) and subsequently updated for the thermodynamic module and the or- 
Table 4. Breakdown of global $\mathrm{SO}_{x}$ deposition fluxes (percent).

\begin{tabular}{lrrrrrr}
\hline & $\begin{array}{r}\text { GEOS-Chem } \\
(2000-2005) \\
\text { Base }\end{array}$ & $\begin{array}{r}\text { Lamarque et al. (2013) } \\
(2000)\end{array}$ & $\begin{array}{r}\text { GEOS-Chem } \\
(2000-2005) \\
\text { G4-Base }\end{array}$ & $\begin{array}{r}\text { ULAQ-CCM } \\
(2030-2039) \\
\text { Base }\end{array}$ & $\begin{array}{r}\text { Lamarque et al. (2013) } \\
(2030 \text { RCP4.5) }\end{array}$ & $\begin{array}{r}\text { ULAQ-CCM } \\
(2030-2039) \\
\text { G4-Base }\end{array}$ \\
\hline $\mathrm{SO}_{2}$ dry deposition & 27.5 & & 3.2 & 35.7 & 9.7 \\
$\mathrm{SO}_{2}$ wet deposition & 9.8 & & 1.2 & 6.6 & 4.2 \\
$\mathrm{SO}_{4}$ dry deposition & 8.8 & & 6.8 & 6.0 & 3.3 \\
$\mathrm{SO}_{4}$ wet deposition & 53.9 & 41.9 & 10.0 & 51.7 & 41.7 & 40.9 \\
$\mathrm{SO}_{x}$ dry deposition & 36.3 & 58.1 & 90.0 & 58.3 & 5.0 \\
$\mathrm{SO}_{x}$ wet deposition & 63.7 & & & & 57.0 \\
\hline
\end{tabular}

ganic aerosol scheme (http://acmg.seas.harvard.edu/geos/ geos_chem_narrative.html). Stratospheric aerosol simulation is split in two main components: liquid and solid (Eastham et al., 2014). The former includes all stratospheric sulfate aerosols, ranging from $\mathrm{H}_{2} \mathrm{SO}_{4}$ liquid binary solutions (LBSs) to a supercooled ternary solution (STS). The latter consists of type Ib and type II polar stratospheric clouds (PSCs), made up of nitric acid trihydrate (NAT) and ice. Up-to-date heterogeneous chemistry reactions are included in the mechanism (Eastham et al., 2014). Photolysis rates for both the troposphere and the stratosphere are calculated using the Fast-JX code (Bian and Prather, 2002).

Dry deposition is calculated with the resistance-in-series scheme proposed by Wesely (1989) and implemented in GEOS-Chem as described by Wang et al. (1998) for gases and Zhang et al. (2001) for aerosols. Aerosol gravitational settling in the stratosphere is described in Eastham et al. (2014). The wet-deposition scheme is implemented as described in Amos et al. (2012) for gases and Liu et al. (2001) for water-soluble aerosols.

\section{Stratospheric sulfate aerosols}

In this section we analyze the distribution and lifetime of the injected stratospheric aerosols first by looking at the multiannual average for both models and then by looking at the time-dependent modifications of the sulfate lifetime caused by oscillations of the stratospheric dynamics.

\subsection{Time-averaged sulfate distribution}

The ULAQ-CCM ability in producing a correct confinement of sulfate aerosols in the tropical stratosphere in SG or postvolcanic conditions has already been extensively tested, with comparison with SAGE II data following the Pinatubo eruption (see Pitari et al., 2014, 2016b; Visioni et al., 2017b). A fully comparable behavior is also shown in GEOS-Chem, which, on the other hand, was not tested before with regard to a stratospheric sulfur injection. In Fig. 1 we show the zonally averaged $\mathrm{SO}_{4}$ mixing ratio averaged over the simulation period for both models, for both Base and G4 experiments ( $\mathrm{SG}$ with $8 \mathrm{Tg} \mathrm{\textrm {SO } _ { 2 }}$ injection). This is done in order to high-

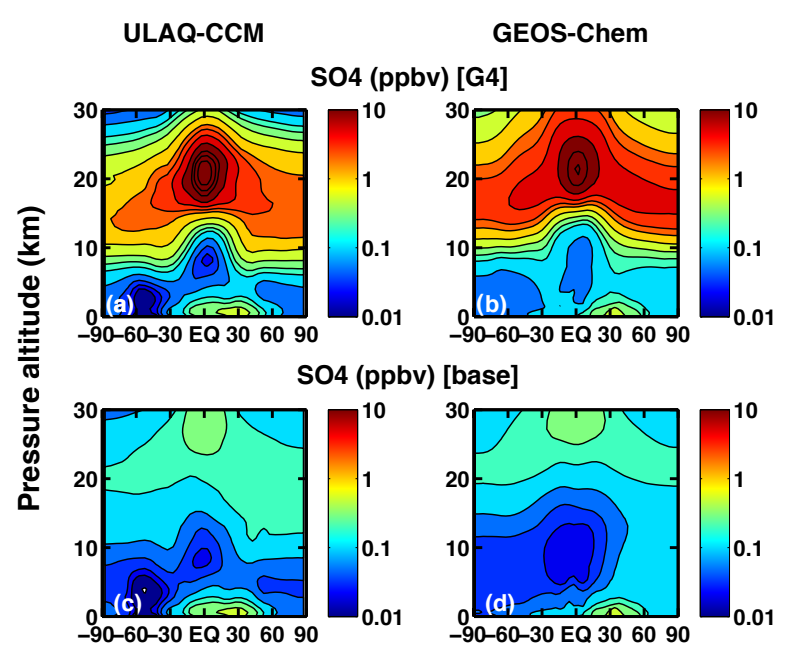

Figure 1. $\mathrm{SO}_{4}$ mixing ratios (ppbv) averaged from 2030 to 2039 for ULAQ-CCM (a, c) and from 2000 to 2005 for GEOS-Chem (b, d). Panels (a) and (b) are for the G4 experiment; (c) and (d) are for the Base experiment. The contour line increment is logarithmic, with three lines per decade.

light similarities between the two models in the stratospheric aerosol tropical confinement, combined with isentropic horizontal mixing in the layer immediately above the tropopause, which enables poleward transport of sulfate from the tropical reservoir.

Although the aerosol confinement looks similar, some differences are still present between the two models. Figure 2a shows the $\mathrm{SO}_{4}$ equatorial vertical profile, corresponding to the zonal mean values in Fig. 1. There is a small but significant difference in the distribution of tropical $\mathrm{SO}_{4}$ between the two cases, with the ULAQ-CCM maximum situated at a somewhat lower altitude with respect to the one predicted by GEOS-Chem. Furthermore, $80 \%$ of the $\mathrm{SO}_{4}$ mass is situated in the 20-70 hPa layer for GEOS-Chem while $78 \%$ of the $\mathrm{SO}_{4}$ mass is confined in the $40-90 \mathrm{hPa}$ layer for ULAQCCM. The reasons for this are substantially two: on the one hand, there is a difference in sulfur injection because ULAQ-CCM injects $\mathrm{SO}_{2}$ with a Gaussian distribution centered at $21.5 \mathrm{~km}$ altitude. In this way, a larger sulfate fraction 

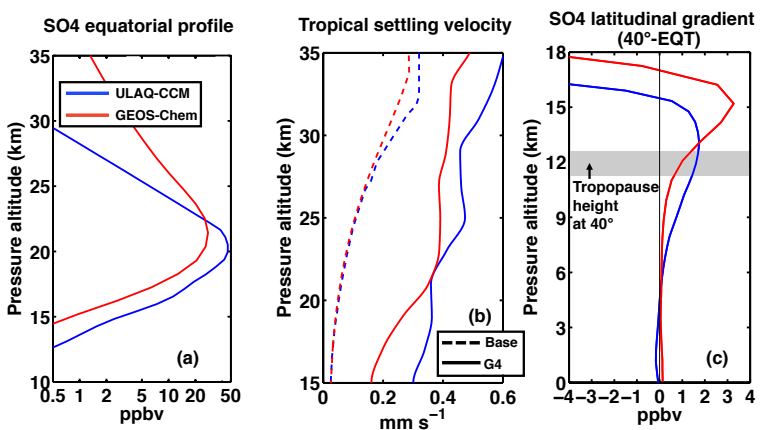

Figure 2. (a) Equatorial $\mathrm{SO}_{4}$ profiles (ppbv) for ULAQ-CCM (blue) and GEOS-Chem (red), in the G4 experiment (panels a, b of Fig. 1). (b) Tropical settling velocities $\left(\mathrm{mm} \mathrm{s}^{-1}\right)$ for the two models (averaged $20^{\circ} \mathrm{S}-20^{\circ} \mathrm{N}$ ), with dashed and solid lines for Base and G4 experiments, respectively. (c) Latitudinal $\mathrm{SO}_{4}$ gradient (ppbv), calculated in the $\mathrm{G} 4$ experiment as the mixing ratio difference between $40^{\circ}\left(40^{\circ} \mathrm{S}\right.$ and $40^{\circ} \mathrm{N}$ average) and the equator.

is kept in the 19-21 km band, with respect to the one resulting from the GEOS-Chem SG simulation, where sulfur is injected uniformly in the $18-25 \mathrm{~km}$ altitude band. This is consistent with differences found in the aerosol vertical distribution between ULAQ-CCM and GEOSCCM (Goddard Earth Observing System climate-chemistry model) in Visioni et al. (2017b), where similar $\mathrm{SO}_{2}$ injections were adopted in the two models. On the other hand, GEOS-Chem uses a bulk approach for sulfate aerosols, with an assumed aerosol effective radius smaller with respect to the one ULAQ-CCM calculates from a predicted aerosol size distribution with a sectional approach (see Table 1). Some differences will then result in the tropical settling velocities of the aerosol particles, as shown in Fig. 2b, from which we may expect a somewhat enhanced downward displacement in ULAQ-CCM.

A third difference is shown in Fig. 2c: the latitudinal gradient of $\mathrm{SO}_{4}$ at the altitude of the midlatitude tropopause (and also a few kilometers below it) is larger in ULAQ-CCM with respect to GEOS-Chem. This results from a slower uppertropospheric horizontal mixing in ULAQ-CCM and does not allow (with respect to GEOS-Chem) the same amount of tropospheric tropical influx of sulfate moving downwards from the region where the large-scale stratosphere-troposphere exchange (STE) is at a maximum. Implications of this effect on the latitudinal distribution of sulfur deposition will be discussed ahead.

Once the injected sulfate has reached a steady state, it has to come down at a rate of $4 \mathrm{Tg} \mathrm{S} \mathrm{yr}^{-1}$, the same rate at which it is injected. In Fig. 3 a budget scheme of geoengineering sulfur fluxes is presented for both models (G4-Base). Sulfate aerosols, formed in the tropical lower stratosphere after the oxidation of $\mathrm{SO}_{2}$ injected continuously at the equator above the tropopause, may leave the tropical pipe in two ways: less than half (according to the models) is removed directly across the tropical tropopause, due to particle gravitational

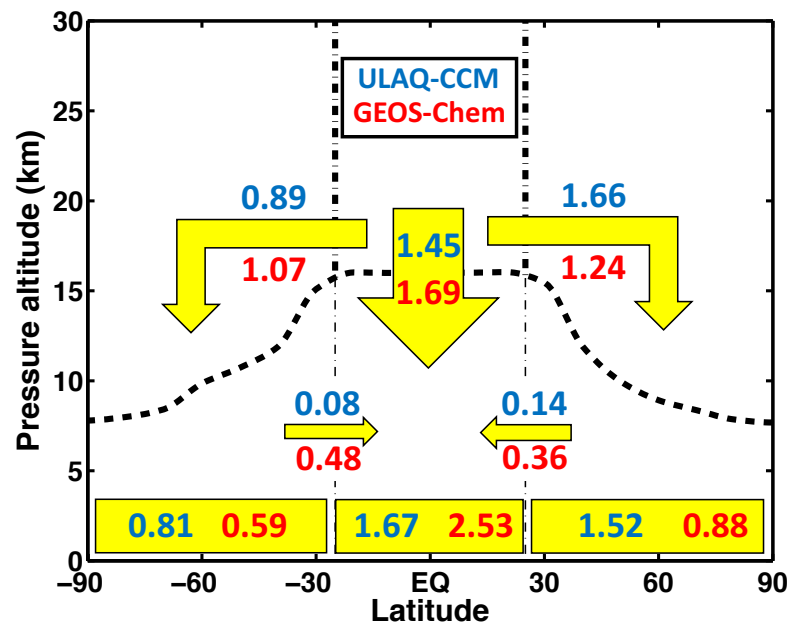

Figure 3. Breakdown of geoengineering sulfur fluxes for ULAQCCM (blue - average 2030-2039) and GEOS-Chem (red - average 2000-2005). The dashed line represents the mean tropopause; the dashed-dotted lines represent the subtropical barriers. The lowermost boxes represent sulfur surface deposition. All values are in $\mathrm{Tg} \mathrm{S} \mathrm{yr}^{-1}$.

sedimentation and large-scale downwelling taking place in limited regions of the tropical tropopause; the rest is moved horizontally out of the tropics via poleward isentropic transport. Once the sulfate aerosols have reached the subtropics and midlatitudes, they may be efficiently removed from the stratosphere by extratropical STE in the lower branch of the Brewer-Dobson circulation (and to a lesser extent via particle gravitational sedimentation).

The two models agree on the general partitioning of stratospheric sulfur fluxes, although some differences are present, especially in the horizontal flux moving toward the Northern Hemisphere midlatitudes, which is $0.42 \mathrm{Tg} \mathrm{S} \mathrm{yr}^{-1}$ larger in ULAQ-CCM compared to GEOS-Chem. A larger intermodel difference is found in the tropospheric mixing from the midlatitudes toward the tropics. The upper-tropospheric tropical influx of sulfur is calculated to be much larger in GEOS-Chem $\left(0.84 \mathrm{Tg} \mathrm{S} \mathrm{yr}^{-1}\right)$ with respect to ULAQCCM $\left(0.22 \mathrm{Tg} \mathrm{S} \mathrm{yr}^{-1}\right)$, thus explaining the larger uppertropospheric latitudinal gradient of geoengineering sulfate presented in Fig. 2c. This difference is then reproduced in the zonally averaged deposition, which presents an excess deposition of $0.86 \mathrm{Tg} \mathrm{S} \mathrm{yr}^{-1}$ in the tropics in GEOS-Chem with respect to ULAQ-CCM. The discussion on deposition results will be further expanded in Sect. 4.

\subsection{QBO impact on stratospheric sulfate}

Previous studies (Aquila et al., 2014; Niemeier and Timmreck, 2015) have focused on the potential effects of sulfate geoengineering on the QBO. Aquila et al. (2014), for instance, reported an increasing stratospheric aerosol burden 
the more the QBO shifted to a lower-stratospheric permanent $\mathrm{W}$ phase (i.e., E shear of the mean zonal equatorial winds). On the other hand, the modulation the QBO itself may introduce to the stratospheric aerosol lifetime (and deposition) has not been explored in depth in the case of a geoengineering constant tropical injection of sulfur. This effect, however, was studied for the time evolution of the unperturbed stratospheric aerosol layer by Hommel et al. (2015). They found that the aerosol burden nonlinearly correlated with the QBO phase for a wide range of reasons, amongst those being the rather large differences in the size range of the aerosols. The QBO impact on the e-folding time of stratospheric sulfate aerosols injected in past major volcanic eruptions was studied in Pitari et al. (2016b), where a clear correlation is found between a larger e-folding time and a QBO E shear of the mean zonal equatorial winds, as a consequence of a higher aerosol confinement in the tropical pipe (consistently with the findings of Trepte and Hitchman, 1992). It should be noted that the stratospheric aerosol distribution in the case of SG, or after a major tropical explosive volcanic eruption, is so different with respect to the atmospheric background, both spatially and in size (see Fig. 1 and Table 1), that the expected QBO impact might significantly differ in the two cases.

Figure 4 presents a schematic representation of the interactions between the QBO and stratospheric sulfate aerosols. The QBO modulation of the mean zonal wind shear and (indirectly) of the stratospheric mean meridional circulation may efficiently impact the tropical pipe confinement of atmospheric tracers. This, in turn, is expected to produce changes in the global-scale aerosol distribution and lifetime, thus modulating the lower-stratospheric aerosol heating rates. QBO-driven changes in aerosol distribution and lifetime in turn produce modifications of the STE, which eventually regulates the latitudinal distribution of the sulfur deposition. Direct QBO effects may be visible both in models with prescribed circulation (CTMs) and with calculated dynamics via chemistry-climate coupling (CCMs), whereas the effects of changes in aerosol heating rates can only be seen in CCMs. The ULAQ-CCM does not include an internally generated QBO but instead uses a nudging approach (see Table 1), so that the schematic representation in Fig. 4 shows the further modification of the QBO by the aerosol heating rates as a possible significant effect (Aquila et al., 2014; Niemeier and Timmreck, 2015), but this is not explored in the present work.

In the lower part of the Fig. 4 scheme, we focused on how the aerosol lifetime is modulated by QBO. On the one hand, the lifetime depends on particles size. With an increased tropical confinement (E shear), the sulfate aerosols have more time to grow through coagulation and gas condensation, with resulting larger particles that may sediment faster, thus enhancing the tropospheric influx and decreasing the stratospheric lifetime. On the other hand, the aerosol lifetime is regulated by how long they may remain confined in the tropical pipe. Once transported to the subtropics and to the midlat-

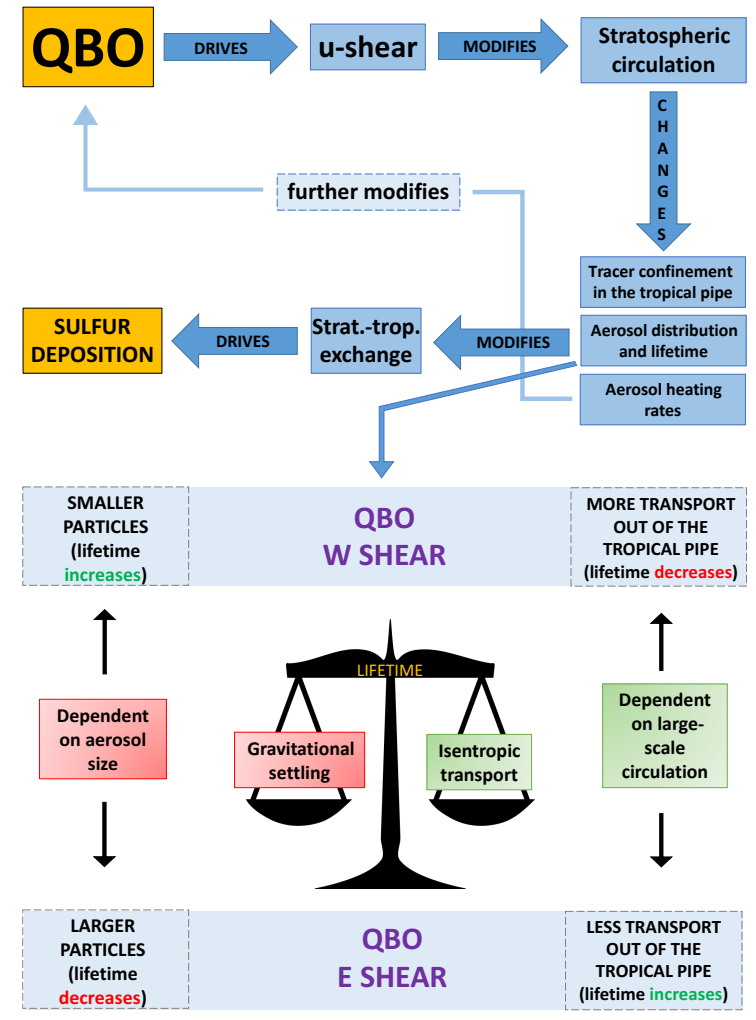

Figure 4. Upper part: schematic links between QBO, stratospheric circulation, geoengineering aerosol lifetime, stratospheretroposphere exchange, sulfur deposition at the surface. Lower part: schematic balance of the two main effects regulating the sulfate aerosol lifetime, starting from the driving QBO wind shear.

itudes by means of lower-stratospheric poleward isentropic transport, the aerosol may effectively be removed from the stratosphere by STE; this extratropical horizontal transport is favored during a QBO W shear (Trepte and Hitchman, 1992). The lower part of Fig. 4 is an attempt to represent the "balance" between the competing QBO-effects that regulate the stratospheric aerosol lifetime.

In Figs. 5 and 6 we present the stratospheric sulfate lifetime time series (Fig. 5 for ULAQ-CCM and Fig. 6 for GEOS-Chem) correlated with the QBO-driven changes in dynamical quantities, as presented in Fig. 4. The lifetime of the injected sulfate is calculated as the stratospheric burden in the G4 case minus the stratospheric burden in the Base case divided by the integrated stratospheric loss of the sulfate, which at the steady state (on average) is equal to the source, that is $4 \mathrm{Tg} \mathrm{Syr}^{-1}$. In Figs. 5a and 6a the lifetime (in black) is compared with the equatorial mean zonal wind shear (in red). This shear is calculated differently for the two models, considering the differences already discussed in the vertical extent of most of the sulfate burden (Fig. 2a). For both models we observe an oscillation of the lifetime that is strongly anticorrelated with the equatorial $u$ shear, with positive values (W shear) connected with a shorter lifetime. 
Since during a $\mathrm{W}$ shear, a decreased equatorial upwelling is present (see Trepte and Hitchman, 1992), we see in Figs. 5b and $6 \mathrm{~b}$ how the oscillations of the residual vertical velocity $(w *)$ anomalies are positively correlated with the lifetime oscillations, considering the $w *$ value at the center of the vertical layer where the largest fraction of the tropical aerosol mass is confined. This is because during periods of QBO W shear, a smaller amount of tropical aerosols is moved upwards to the mid-stratosphere and a larger amount remains displaced in the lower part of the tropical pipe, where horizontal isentropic mixing with the extratropics is faster. Lastly, in Figs. 5c and 6c we show the meridional mass flux anomalies at the edges of the tropical pipe, which is smaller during E shear periods (due to the reduced isentropic transport immediately above the tropopause), such that they are anticorrelated with the lifetime oscillations.

Although both models agree with the response of the lifetime to changes in stratospheric dynamics, some differences between the models are visible. First of all, as seen in Table 1, the average aerosol lifetime is different for the two models (12.1 months for ULAQ-CCM against 13.5 months for GEOS-Chem). This might be due to a series of factors, amongst those a different $r_{\text {eff }}$ for the sulfate aerosol $(0.62 \mu \mathrm{m}$ in GEOS-Chem and $0.78 \mu \mathrm{m}$ in ULAQ-CCM, as equatorial LS (lower stratosphere) values) and a different treatment of the aerosol microphysics itself (bulk approach with diagnosed effective radius in GEOS-Chem and explicitly calculated size distribution approach for ULAQ-CCM). The lifetime oscillations are also of a different magnitude: in this case the difference might in part be explained by looking at the ULAQ-CCM results using the Base case circulation (i.e., with a CTM-like approach; see Fig. 5b). The decreased amplitude of the sulfate lifetime oscillations when the Base case circulation is used in the G4 case originates from the missing aerosol radiative feedback on dynamics and the consequent lack of additional tropical upwelling due the stratospheric aerosol heating rates $(w *=0.22 \pm 0.12$ for the CCM approach and $0.20 \pm 0.09$ for the CTM approach, as a 20$70 \mathrm{hPa}$ equatorial mean). A $25 \%$ reduction is found for the tropical upwelling time variability expressed with the standard deviation of monthly mean values in the 2030-2039 decade. Another reason for the decreased amplitude of the sulfate lifetime oscillations should be found in the missing impact on lower-stratospheric horizontal eddy mixing of decreasing SSTs in G4 with respect to the Base case (see Visioni et al., 2017b; $\Phi_{V}=2.55 \pm 0.56 \mathrm{Tg} \mathrm{S} \mathrm{yr}^{-1}$ for the CCM approach and $2.34 \pm 0.42 \mathrm{Tg} \mathrm{S} \mathrm{yr}^{-1}$ for the CTM-like approach; again with a $25 \%$ reduction in the net poleward meridional sulfate mass flux, integrated vertically above the tropopause at the subtropical barriers).

The interannual variability in the sulfate lifetime is smaller in GEOS-Chem (0.3 months) than in ULAQ-CCM (1.2 months) but closer to the latter when the ULAQ model is operated in CTM mode (0.6 months), i.e., using the Base circulation for the G4 case, without includ-
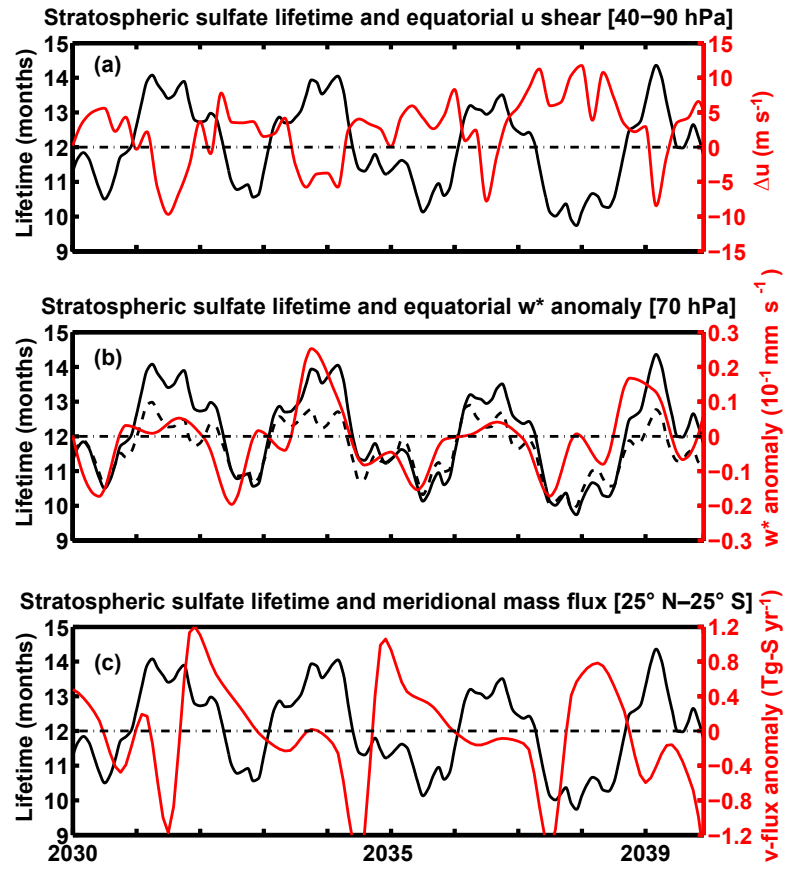

Figure 5. (a) Monthly means of geoengineering $\mathrm{SO}_{4}$ lifetime (black; left scale; months) and equatorial zonal wind shear between 40 and $90 \mathrm{hPa}$ (red; right scale; $\mathrm{ms}^{-1}$ ) in the ULAQCCM (years 2030-2039). (b) $\mathrm{SO}_{4}$ lifetime, as in (a) but compared against the $70 \mathrm{hPa}$ equatorial $w *$ anomalies (red; right scale; $\mathrm{mm} \mathrm{s}^{-1}$ ). The calculated average lifetime of stratospheric sulfate from geoengineering sulfur injection of $8 \mathrm{Tg} \mathrm{SO}_{2} \mathrm{yr}^{-1}$ is $12.1 \pm 1.2$ months in ULAQ-CCM (with an equatorial residual vertical velocity $w *=0.22 \pm 0.12 \mathrm{~mm} \mathrm{~s}^{-1}$, as a time average between 20 and $70 \mathrm{hPa}$ ). The average lifetime decreases to $11.6 \pm 0.6$ months when using winds from the baseline simulation, i.e., in a CTM approach (black dashed curve) (see text for discussion). (c) $\mathrm{SO}_{4}$ lifetime, as in (a) but compared against the net poleward meridional sulfate mass flux anomalies integrated above the tropopause at the subtropical barriers at $25^{\circ} \mathrm{S}$ and $25^{\circ} \mathrm{N}$ (red; right scale; $\mathrm{Tg} \mathrm{S} \mathrm{yr}^{-1}$ ). The meridional flux is defined as $v \times\left[\mathrm{SO}_{4}\right]$ and defined as positive when poleward, i.e., $\Phi_{V}=v\left[\mathrm{SO}_{4}\right]\left(25^{\circ} \mathrm{N}\right)-v\left[\mathrm{SO}_{4}\right]\left(25^{\circ} \mathrm{S}\right)$, where $v$ is the meridional wind and $\left[\mathrm{SO}_{4}\right]$ the sulfate concentration $\left(\Phi_{V}=2.55 \pm 0.56 \mathrm{Tg} \mathrm{S} \mathrm{yr}^{-1}\right)$.

ing the aerosol radiative feedback on dynamics. The remaining difference is mainly connected with the different QBO treatment in the two models (assimilated wind fields for GEOS-Chem, nudged observed zonal winds in the equatorial stratosphere for ULAQ-CCM; $w *=0.14 \pm 0.06 \mathrm{~mm} \mathrm{~s}^{-1}$ and $v=2.31 \pm 0.38 \mathrm{Tg} \mathrm{S} \mathrm{yr}^{-1}$ in GEOS-Chem, both defined as above for the ULAQ model). An additional 33 and $10 \%$ reductions in the time variability are found with respect to the ULAQ model operated in CTM mode, for tropical upwelling and the subtropical sulfate mass flux, respectively.

The link between QBO-driven transport oscillations and the sulfate aerosol particle size, already presented in Fig. 4, is presented in Fig. 7 using ULAQ-CCM results. In Fig. 7a 

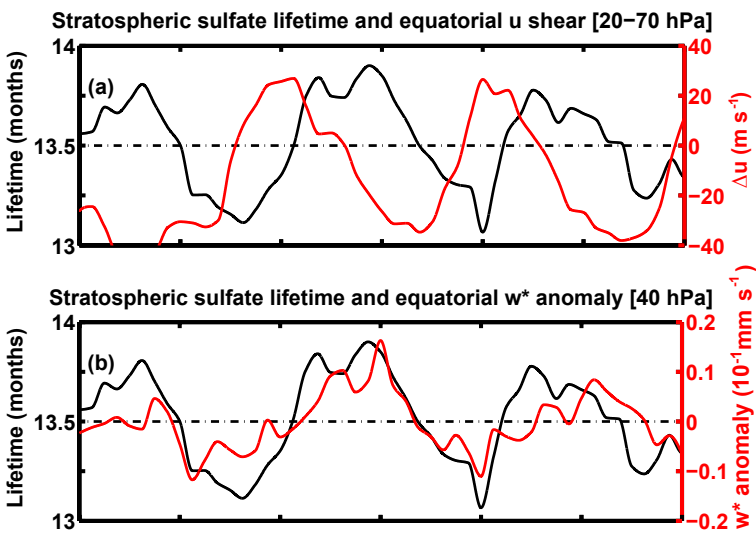

Stratospheric sulfate lifetime and meridional mass flux $\left[25^{\circ} \mathrm{N}-25^{\circ} \mathrm{S}\right]$

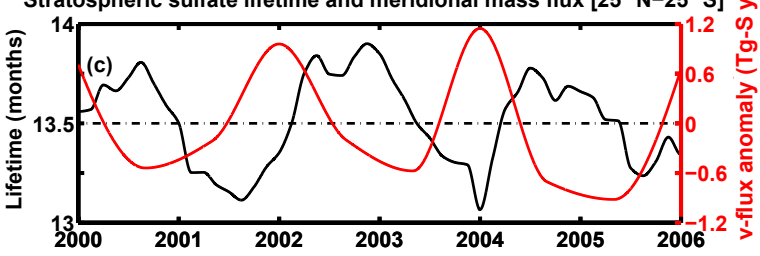

Figure 6. As in Fig. 5 but for GEOS-Chem for the years 2000-2005. The calculated average lifetime of stratospheric sulfate from geoengineering sulfur injection of $8 \mathrm{Tg} \mathrm{SO}_{2} \mathrm{yr}^{-1}$ is $13.5 \pm 0.3$ months in GEOS-Chem (equatorial residual vertical velocity $w *=0.14 \pm 0.06 \mathrm{~mm} \mathrm{~s}^{-1}$, as a time average between 20 and $70 \mathrm{hPa}$; net poleward meridional sulfate flux out of the tropical pipe $\Phi_{V}=2.31 \pm 0.38 \mathrm{Tg} \mathrm{S} \mathrm{yr}^{-1}$, as a time average at $25^{\circ} \mathrm{S}$ and $25^{\circ} \mathrm{N}$ latitude above the tropopause). The monthly variability in the sulfate lifetime (0.3 months) is smaller than in ULAQ-CCM (1.2 months) but closer to the latter when the ULAQ model is operated in CTM mode (0.6 months), i.e., using the Base circulation for the G4 case, without including the aerosol radiative feedback on dynamics (see text).

we show how a longer lifetime is connected to a larger tropical effective radius. This is a consequence of what we showed in Fig. 5b, with the lifetime being longer under an E shear, when $w *$ presents positive anomalies and $\Phi_{V}$ negative anomalies. As presented in Fig. 4, a higher tropical confinement favors the enhancement of microphysical processes responsible for particle growth (gas condensation and coagulation). While the average effective radius $r_{\text {eff }}$ is $0.70 \mu \mathrm{m}$ over the whole decade, when considering only years with a QBO E shear, we obtain a value of $r_{\text {eff }}=0.75 \mu \mathrm{m}$, against $r_{\text {eff }}=0.66 \mu \mathrm{m}$ for years with a dominant $\mathrm{W}$ shear. This implies a $13 \%$ change in the average effective radius between the two QBO regimes. In Fig. 7b we show that this increased particle size in turn produces a smaller tropical aerosol optical depth (AOD) at $\lambda=0.55 \mu \mathrm{m}$, due to a decreased scattering efficiency of the sulfate particles themselves. This is because the extinction coefficient at $0.55 \mu \mathrm{m}$ varies greatly around the maximum and minimum values of the radii shown in Fig. 7a, with a peak closer to the values found under a W
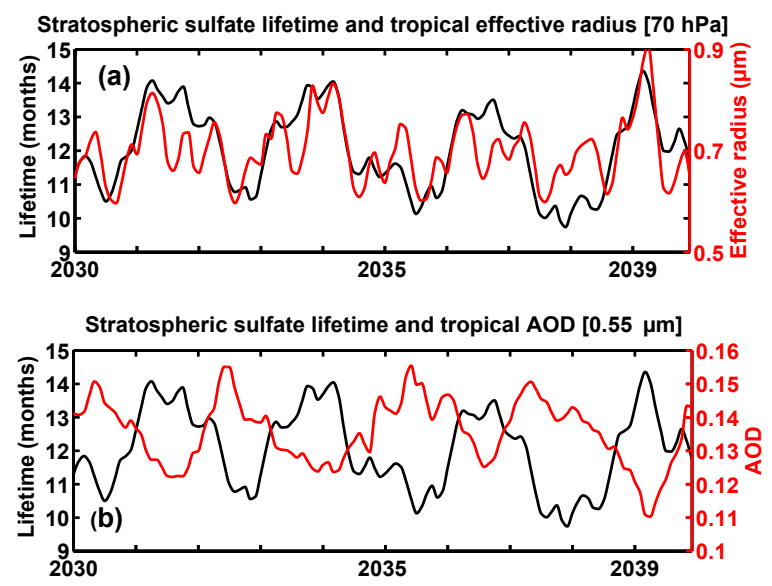

Figure 7. (a) Monthly means of geoengineering $\mathrm{SO}_{4}$ lifetime (black; left scale; months) and tropical effective radius at $70 \mathrm{hPa}$ (red; right scale; $\mu \mathrm{m} ; 20^{\circ} \mathrm{S}-20^{\circ} \mathrm{N}$ ) for ULAQ-CCM (years 2030 2039). (b) $\mathrm{SO}_{4}$ lifetime, as in (a) and tropical aerosol optical depth at $0.55 \mu \mathrm{m}\left(20^{\circ} \mathrm{S}-20^{\circ} \mathrm{N}\right)$. Average values in the 2030-2039 decade are $r_{\text {eff }}=0.70 \pm 0.06 \mu \mathrm{m}$, tropical $\mathrm{AOD}=0.136 \pm 0.010$, global $\mathrm{AOD}=0.079 \pm 0.003$. The calculated all-sky tropopauseadjusted radiative forcing from stratospheric geoengineering sulfate (G4-Base) is $-1.73 \pm 0.07$ (shortwave), $+0.53 \pm 0.02$ (longwave) and $-1.20 \pm 0.05 \mathrm{~W} \mathrm{~m}^{-2}$ (net). The E-W shear average anomaly of the net RF (radiative forcing) is calculated to be $+0.06 \mathrm{~W} \mathrm{~m}^{-2}$ (i.e., when the lifetime is longer, there is an average $4 \%$ decrease in the long-term calculated net RF).

shear. This result appears to be in line with the findings of Niemeier and Schmidt (2017) and Kleinschmitt et al. (2017) regarding particle growth under different QBO wind shears and its effect on AOD and forcing efficiency (although in their case the QBO reacted to sulfate injection and their $\mathrm{SO}_{2}$ injection was larger with respect to the one adopted in the present study). In years with a dominant $\mathrm{W}$ shear, the tropical AOD is maximized with an average value of 0.144 , which is reduced to 0.127 during years with a dominant $E$ shear. In our calculations, this in turn produces an $8.5 \%$ difference in the net radiative forcing between the two QBO regimes, with a decadal average value of $-1.20 \mathrm{~W} \mathrm{~m}^{-2}$ (all-sky conditions).

Lastly, we show in Fig. 8 how the oscillations in the stratospheric sulfate lifetime are correlated with changes in sulfur ground deposition. In order to avoid masking the interannual variability in surface deposition with the seasonal component, a detrending method has been applied to retain only interannual changes. Furthermore, the deposition values have been shifted by 8 months, in order to show how the stratospheric sulfate lifetime is well correlated with the deposition changes (G4-Base) after the time needed for the particles in the tropical pipe to reach the tropopause. We have estimated this time close to 8 months, considering both isentropic transport out of the tropical pipe and settling of the particles from the height at which they are produced down to the tropical 
(a) Stratospheric sulfate lifetime and deposition changes

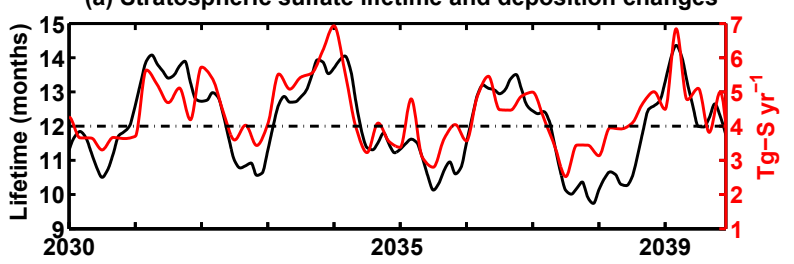

(b) Stratospheric sulfate lifetime vs. deposition changes

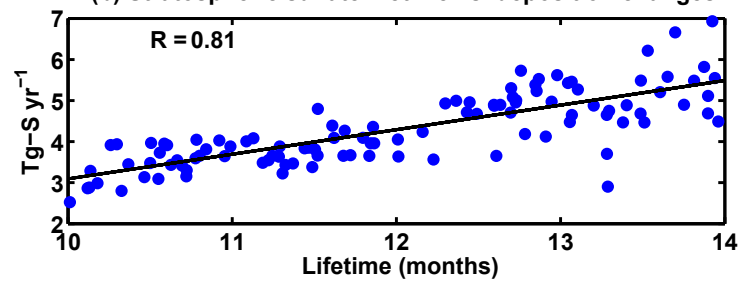

Figure 8. (a) Monthly means of geoengineering $\mathrm{SO}_{4}$ lifetime (black; left scale; months) and sulfur deposition changes (G4-Base) (red; right scale; $\mathrm{Tg} \mathrm{S} \mathrm{yr}^{-1}$ ) for ULAQ-CCM (years 2030-2039). To highlight the correlation between the stratospheric $\mathrm{SO}_{4}$ lifetime and the sulfate deposition, the monthly values of the latter have been treated as follows: (1) an annual mean cycle was first calculated over the whole decade; the annual variability was then removed, in order to keep the interannual variability alone; (2) detrended monthly deposition values were finally shifted ahead by 8 months. This latter value was chosen for optimizing the correlation and is close the average time needed for G4 aerosols formed in the stratospheric tropical pipe to reach the tropopause, where they are exchanged with the troposphere and finally lost by surface deposition. (b) Scatterplot of the values presented as time series in (a) (0.81 correlation coefficient). A comparable behavior is also found in the GEOS-Chem results (not shown), with a 0.92 correlation between monthly values of the stratospheric sulfate lifetime and detrended monthly deposition values with 8 months' lag.

tropopause. The scatterplot in Fig. $8 \mathrm{~b}$ shows the good correlation of the stratospheric sulfate lifetime (on monthly basis) with detrended and time-shifted deposition change values.

\section{Sulfur deposition}

In the previous section, the physical mechanisms regulating the stratospheric sulfate mean distribution and abundance have been discussed, along with its interannual variability under SG conditions. Figure 8 has proven that interannual oscillations in large-scale stratospheric transport not only regulate the integrated sulfate mass above the tropopause (i.e., the SG lifetime) but also the globally integrated surface deposition changes in sulfur. In this section we analyze, both globally and on a continental scale, how SG surface deposition is regulated by cross-tropopause downward fluxes. We will also evaluate the model-calculated background surface deposition of sulfur and quantify absolute and relative deposition changes due to SG, looking also at the QBO-driven variability in the deposition. (a) Sulfur deposition ( $\mathrm{mg}-\mathrm{S} \mathrm{m} \mathrm{m}^{-2} \mathrm{yr}^{-1}$ )

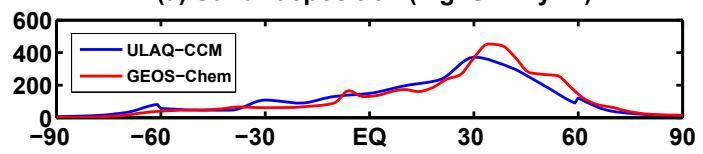

(b) Sulfur deposition changes $\left(\mathrm{mg}-\mathrm{S} \mathrm{m}^{-2} \mathrm{yr}^{-1}\right)$

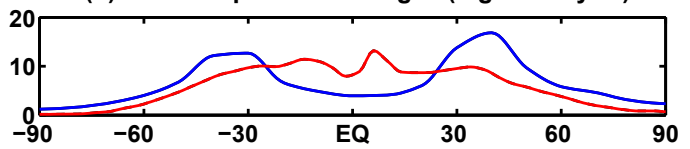

(c) Sulfur deposition changes (percent)

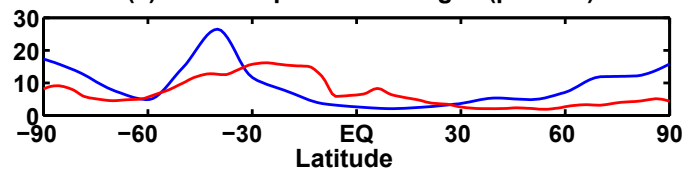

Figure 9. (a) Zonally annually averaged sulfur deposition fluxes in the baseline experiment ( $\mathrm{mg} \mathrm{S} \mathrm{m}^{-2} \mathrm{yr}^{-1}$ ), for ULAQ-CCM (blue - years 2030-2039) and GEOS-Chem (red - years 2000-2005). (b) As in (a) but for the sulfur deposition flux changes (G4-Base). (c) As in (b) but in percent of the Base case.

\subsection{Global- and continental-scale time-average deposition}

The model-calculated zonally averaged sulfur deposition in baseline conditions is presented in Fig. 9a: as expected from the short tropospheric sulfur lifetime $\left(\sim 5\right.$ days for $\mathrm{SO}_{4}$ and 1-2 days for $\mathrm{SO}_{2}$ and DMS) and from the modelconsistent global and regional sulfur emission fluxes (see Tables 1-3), the annually and zonally averaged sulfur deposition (dry + wet, $\mathrm{SO}_{2}+\mathrm{SO}_{4}$, Base case) does not show significant departures between GEOS-Chem and ULAQ-CCM. Following the latitudinal pattern of anthropogenic fossil fuel $\mathrm{SO}_{2}$ emissions, most of the background deposition is confined to the NH midlatitudes, producing a large interhemispheric asymmetry.

Annually and zonally averaged sulfur deposition changes due to SG (i.e., G4-Base) are presented in Fig. 9b. Here a significant difference between the two models is visible: deposition changes in ULAQ-CCM peak at the subtropics up to approximately $45^{\circ}$ latitude in both hemispheres $\left(\sim 15 \mathrm{mg} \mathrm{S} \mathrm{m}^{-2} \mathrm{yr}^{-1}\right)$, with smaller values in the tropics $\left(\sim 4 \mathrm{mg} \mathrm{S} \mathrm{m}^{-2} \mathrm{yr}^{-1}\right.$ ), which reflects the large-scale STE latitudinal pattern, coupled to the cross-tropopause aerosol sedimentation flux. The deposition change peak in the $\mathrm{NH}$ is larger than in the SH by approximately $50 \%$, consistently with the larger stratospheric poleward flux at the $\mathrm{NH}$ tropical barrier $\left(1.66 \mathrm{Tg} \mathrm{S} \mathrm{yr}^{-1}\right)$, with respect to the $\mathrm{SH}$ (0.89 $\mathrm{Tg} \mathrm{S} \mathrm{yr}^{-1}$; see Fig. 3 ). On the other hand, GEOS-Chem predicts a flatter distribution of the zonally averaged sulfur deposition, from the subtropics equatorwards, in both hemispheres. This is again consistent with what shown in Fig. 3, regarding both the tropical sulfur downward flux at the tropopause and the upper-tropospheric equatorward horizon- 
tal mixing at the subtropics. Both are larger in GEOS-Chem with respect to ULAQ-CCM and mainly for the tropical sulfur influx due to tropospheric horizontal mixing.

The large-scale sulfate transport behavior in GEOS-Chem results from downward fluxes at the subtropical tropopause with further downward motion in the troposphere coupled to a significant equatorward component. This is consistent with analyses of the ozone STE made by Hsu et al. (2005), using the University of California at Irvine (UCI) chemistrytransport model. The tropospheric equatorward transport component in the ULAQ-CCM is much weaker, so that the integrated tropical sulfur deposition flux in this model (1.67 $\left.\mathrm{Tg} \mathrm{S} \mathrm{yr}^{-1}\right)$ is significantly smaller than that in GEOSChem (2.53 $\mathrm{Tg} \mathrm{S} \mathrm{yr}^{-1}$ ). Nevertheless, some of the model results presented in Marshall et al. (2017) for the Tambora eruption case, using four independent atmosphere-ocean global circulation models (AOGCMs), highlight distinct sulfur deposition maxima over the midlatitudes, with limited sulfate penetration in the tropical band.

Sulfur deposition changes due to SG are further highlighted in Fig. 9c, where the increased deposition is shown in percent of the Base case. In the NH the increase is typically much less than $10 \%$ (except over the Arctic for ULAQ$\mathrm{CCM}$ ), whereas in the $\mathrm{SH}$ the deposition increase ranges between 10 and $20 \%$, with a $27 \%$ peak for ULAQ-CCM around $40^{\circ} \mathrm{S}$. The interhemispheric asymmetry is largely produced by the much larger $\mathrm{NH}$ deposition of tropospheric sulfur (Fig. 9a).

Looking at the zonally averaged season-dependent sulfur deposition (Fig. S1a, b in the Supplement), it is easy to find the signature of subtropics and midlatitude cross-tropopause stratospheric influx. As is well-documented for ozone (Hsu et al., 2005), as an example for an atmospheric tracer with stratospheric reservoir, the STE reaches maximum values during springtime months at the subtropics, close to $30^{\circ}$ latitude in both hemispheres. The correlation of subtropics and midlatitude monthly maxima of the STE with sulfur deposition maxima is observed in both models, with additional near-equatorial maxima in GEOS-Chem, due to a more efficient upper-tropospheric horizontal mixing in this model (see discussion on Figs. 2c, Sect. 3.1., and 9b, Sect. 4.1). The $\mathrm{STE} \mathrm{O}_{3}$ flux diagnosed in Hsu et al. (2005) shows a significant subtropical influx most of the year, with midlatitude influx important only in spring and summer in the NH. They also note that the $\mathrm{STE} \mathrm{O}_{3}$ flux generally travels further downwards in the troposphere with a significant equatorward component, which is in agreement with the GEOS-Chem findings of a larger equatorward tropospheric mixing of stratospheric sulfate coming from the subtropical STE (as already noted above in the discussion of Fig. 9, Sect. 4.1). Sulfur deposition changes relative to atmospheric unperturbed conditions (Fig. S1cd) are also consistent in the two models, except over the Arctic, where the ULAQ-CCM predicts a significantly larger impact of the SG sulfur deposition with respect to the

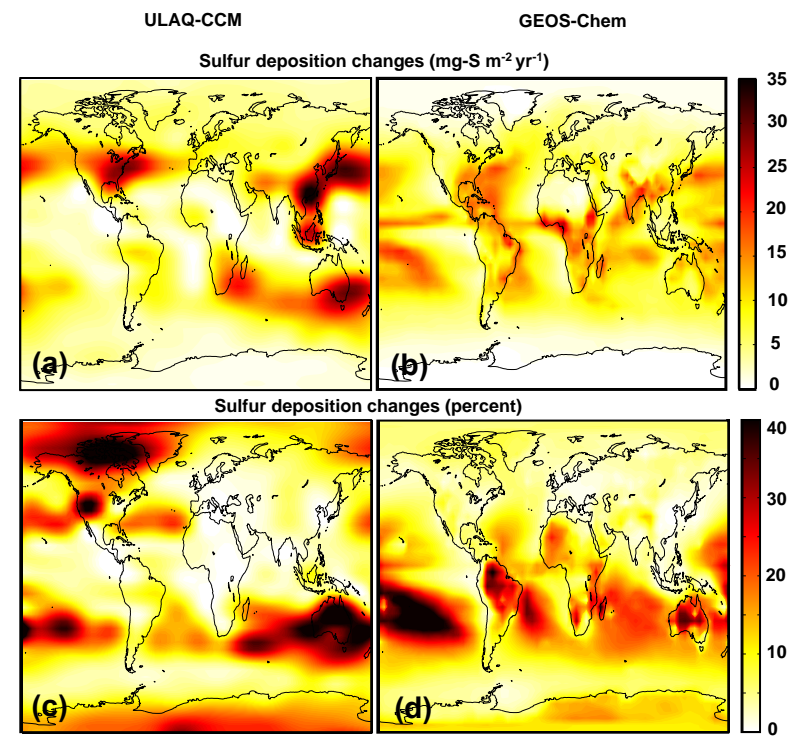

Figure 10. Annually averaged sulfur deposition flux changes (G4Base) as a function of latitude and longitude for ULAQ-CCM in (a) and (c) (years 2030-2039) and GEOS-Chem in (b) and (d) (years 2000-2005). Panels (a) and (b) show absolute changes $\left(\mathrm{mg} \mathrm{S} \mathrm{m}^{-2} \mathrm{yr}^{-1}\right)$; (c) and (d) show percent changes with respect to the Base case.

Base case, pointing to a stronger polar descent (also visible in Fig. 9bc).

Annually averaged sulfur deposition flux changes are shown in Fig. 10, as a function of latitude and longitude. The effects of the tropical sulfate influx in the upper troposphere are clear in the GEOS-Chem deposition fields (Fig. 10b, d), when compared to those of ULAQ-CCM (Fig. 10a, c). In the latter case, a significant tropical deposition is only predicted over southeast Asia (in absolute values). Midlatitude maxima, on the other hand, are fairly consistent between the two models as well as being visible in the $\mathrm{SH}$ percent changes (Fig. 10c, d). Non-zonal asymmetries of midlatitude deposition flux changes result essentially from planetary wave modulation of the stratosphere-troposphere downward flux, coupled to the precipitation frequency in the lower troposphere (see discussion below). Sulfur deposition changes in the polar regions are of the same order of magnitude in the two models only over Antarctica (5-12 in GEOS-Chem and 10-20\% in ULAQ-CCM). The Arctic increase, on the other hand, is much larger in the ULAQ-CCM, with a peak of $35 \%$ east of Greenland; as noted in the discussion of Fig. S1, this is most likely related to a stronger polar descent in the ULAQCCM.

Percent deposition changes are calculated with respect to time-averaged Base values, presented in Fig. S2. A careful evaluation of these values is made on a continental scale, on the basis of regionally integrated values. To do so, we first present in Fig. 11 an evaluation of the Base emission and de- 

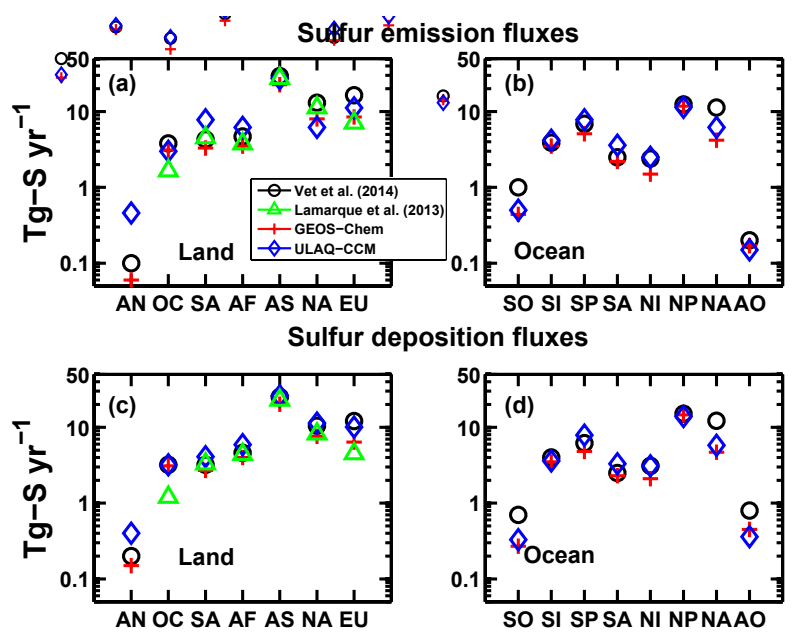

Figure 11. Regional area averaged emission and deposition fluxes of sulfur in (a) and (b), on the one hand, and (c) and (d), on the other, respectively. Values from ULAQ-CCM (blue) and GEOSChem (red) are averaged over the years 2000-2002 (i.e., historical reference experiment for ULAQ-CCM and Base case for GEOSChem). Observations and multi-model averages reported in Vet et al. (2014) and Lamarque et al. (2013) are shown for comparison (years 2001 and 2000, respectively). Land regions are presented in (a) and (c) (Antarctica, Oceania, South America, Africa, Asia, North America, Europe); ocean regions are presented in (b) and (d) (Southern Ocean, South Indian Ocean, South Pacific, South Atlantic, North Indian, North Pacific, North Atlantic, Arctic Ocean).

position fluxes over land and oceans for both models, using the available literature: in particular, we compare our results with Vet et al. (2014), who use a multi-model-observation approach, and Lamarque et al. (2013) who rely on an independent multi-model approach. In particular, the former work allows us to compare emission and deposition fluxes in all land and oceanic regions of the planet, whereas the latter offers regional values for land regions (except Antarctica). The regions are ordered from the southernmost to the northernmost, in order to highlight interhemispheric differences, if present. From Fig. 11a, b we can see that both models correctly reproduce emission fluxes at a regional level, with the correct order of magnitude almost everywhere, both on land and over oceans. A significant model spread is found over Antarctica, where ULAQ-CCM overestimates the Vet et al. (2014) estimate, contrary to GEOS-Chem, which underestimates it. The deposition values presented in Fig. 11a, b are equally consistent, if not more, with Vet et al. (2014) values.

Once sure that both models properly simulate emission and deposition fluxes, we estimated the amount of increased deposition on all regions, produced by the $4 \mathrm{Tg} \mathrm{S} \mathrm{yr}^{-1}$ injection in the equatorial lower stratosphere. These results are shown in Tables S1-S2 in the Supplement and their equivalent graphical form in Fig. 12. The standard deviation given for both models in each region (Fig. 12) represents the in-

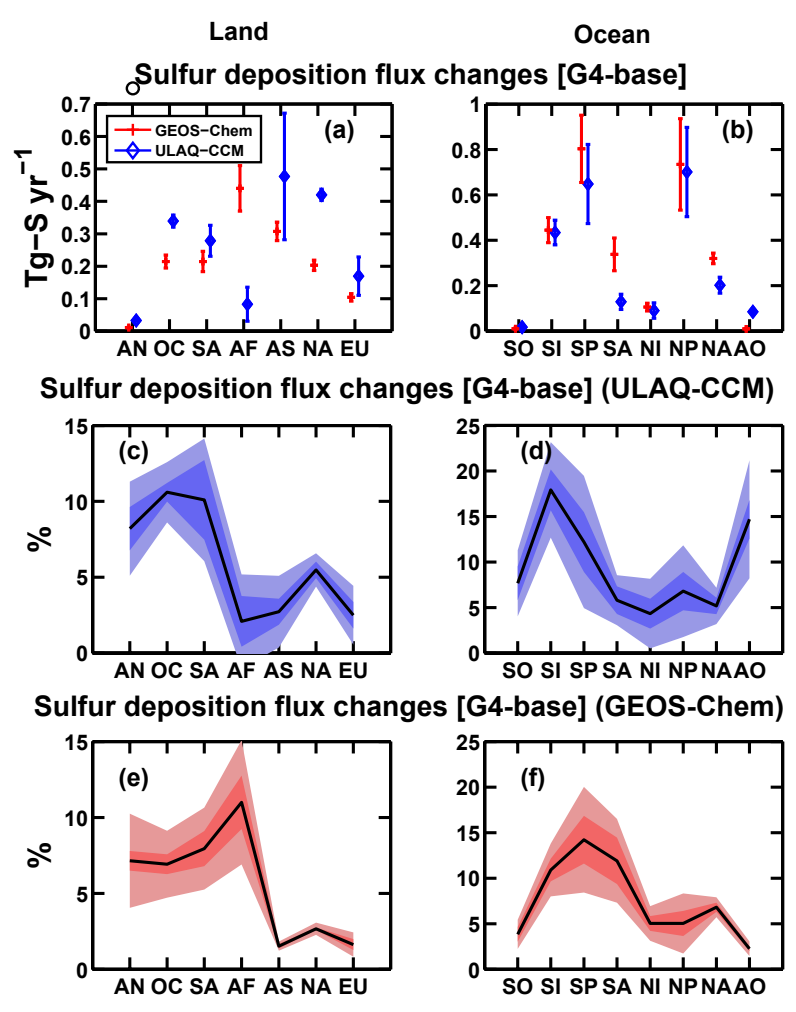

Figure 12. Regional area averaged deposition flux changes in sulfur (G4-Base) for land and ocean regions in (a) and (b), respectively. Regions are those listed in Fig. 11. Whiskers show the standard deviation of detrended monthly deposition change values, for the years 2030-2039 in ULAQ-CCM and 2000-2005 in GEOSChem (annual variability is removed, as seen in Fig. 8, to highlight the impact on surface deposition changes in the stratospheric circulation interannual variability, mainly due to the QBO). Percent changes from ULAQ-CCM are shown in (c) and (d); those from GEOS-Chem are shown in (e) and (f) (both with respect to the Base experiment). Shaded areas (blue for ULAQ-CCM and red for GEOS-Chem) show the standard deviation of monthly deposition percent change values, for the years 2030-2039 in ULAQ-CCM and 2000-2005 in GEOS-Chem. Darker blue/red shaded areas show the standard deviation for detrended monthly deposition change values (with annual variability removed, as seen in Fig. 8 and specified above for $\mathbf{a}$ and $\mathbf{b})$.

terannual variability due to the QBO, as seen in Fig. 8. As already highlighted in Fig. 9, the two models differ in their estimate of the increased sulfur deposition in the tropics, with GEOS-Chem giving a significantly larger deposition change over Africa. As has been shown in Fig. 3, this is a result of both the larger cross-tropopause tropical downward flux and the larger mid- to upper-tropospheric mixing toward tropical latitudes in GEOS-Chem compared to ULAQ-CCM (see also the discussion of Figs. 9-10). When looking at Fig. 12c, e we see that this translates into a much larger relative deposition change over Africa for GEOS-Chem with respect to ULAQ-CCM. 
Considering the imbalance of Base deposition fluxes between $\mathrm{SH}$ and $\mathrm{NH}$ (Fig. 11), we obtain relative changes in panels (c-f) of Fig. 12 that appear much smaller in the $\mathrm{NH}$ (as a whole, an increase of $3.8 \%$ in the Base deposition) compared to $\mathrm{SH}$ values (as a whole, an increase of $10.3 \%$ in the Base deposition). This means that over some regions in the $\mathrm{SH}$, sulfur deposition increases by more than $10 \%$ (Oceania and South America for ULAQ-CCM, with 10.6 and $10.1 \%)$. A rather large difference is also present in percent changes over the Arctic Ocean, with $4.7 \pm 2.2 \%$ for ULAQCCM compared to $2.3 \pm 0.3 \%$ for GEOS-Chem, a difference already shown and presented in Fig. 9. With the average regional deposition percent changes, we also highlight the standard deviation due to both seasonal and interannual changes (darker shading for the latter alone). This visual representation allows us to see that, when looking at single deposition change values, there might be a combination of seasonal and QBO-driven effects that may produce a variability in relative deposition changes with an upper limit as high as $15 \%$ over Africa for GEOS-Chem or as low as close to 0 over Africa and Asia for ULAQ-CCM.

The large difference in the predicted sulfur deposition changes over the Arctic between the two models (as shown in Table S2) warrants a further comparison with measured values, in order to understand whether the models correctly simulate the aerosol transport to polar latitudes. A semiquantitative comparison can be made using values appropriate for past explosive volcanic eruptions, as retrieved from ice cores in Antarctica and Greenland, for example those of the 1815 eruption of Tambora (Sigl et al., 2015; Gao et al., 2007). However, there are many significant differences between a sustained sulfur injection (SG) and an impulsive one (volcanoes) that prevent us from making a precise comparison, as we did for the baseline sulfur deposition fluxes using data from Vet et al. (2014): (1) Atmospheric dynamical conditions of the specific year of the eruption (April 1815, for Tambora) play a decisive role in the subsequent aerosol plume dispersal, both in terms of aerosol lifetime and spatial distribution, with respect to results from a sustained injection. These are in fact "climatologically averaged" over a certain amount of years. (2) The size itself of the aerosols plays an important part in the latitudinal distribution of sulfur deposition (as discussed in Sect. 4.2) and cannot be retrieved from ice cores. (3) The Tambora eruption took place at $8^{\circ} \mathrm{S}$, thus presumably favoring a larger plume dispersal in the Southern Hemisphere, with respect to our SG experiments with equatorial $\mathrm{S}$ injection. Nonetheless, the following comparison can give us a first-approximation idea of how realistic the model estimates are in terms of $\mathrm{S}$ deposition over the polar regions. By normalizing the deposition fluxes to the amount of injected sulfur (as done for the models in Table S2) and considering that the sulfur injection from the Tambora eruption is estimated to be close to $60 \mathrm{Tg} \mathrm{SO}_{2}$, we obtain observed normalized values of $0.0035 \mathrm{Tg} \mathrm{S}$ for Greenland and $0.024 \mathrm{Tg}$ S for Antarctica. The ULAQ-CCM calculated nor- malized S deposition in the two regions ( 0.0027 for Greenland and $0.0075 \mathrm{Tg} \mathrm{S} \mathrm{yr}^{-1}$ for Antarctica) comes closer to the estimated (scaled) values from ice cores, compared to the calculated normalized deposition in GEOS-Chem (0.0010 for Greenland and $0.0025 \mathrm{Tg} \mathrm{S} \mathrm{yr}^{-1}$ for Antarctica).

\subsection{QBO impact on global-scale deposition}

In this section we will show how our results discussed in Sect. 3 regarding the role of SG stratosphere-troposphere downward fluxes can be linked to the sulfate deposition flux changes discussed in Sect. 4.1 and presented in Fig. 10a.

In order to do so, we show the time-averaged G4-Base changes in the downward cross-tropopause sulfur flux for the ULAQ-CCM in Fig. 13a . Its maxima resemble a planetary wavenumber 1-2 modulation of the lower-stratospheric poleward sulfate transport from the tropical pipe reservoir, thus consequently producing non-zonal asymmetries in the tropospheric sulfate influx. The tropospheric convective vertical mixing coupled to wet scavenging produces a tropospheric sulfate lifetime of approximately 5 days in the ULAQ-CCM (Pitari et al., 2016a). In a first approximation, zonal transport operated by the westerlies tends to move the downwardmoving sulfate coming from the tropopause by approximately $6500 \mathrm{~km}$ in a time period comparable to the tropospheric sulfate lifetime. This seems roughly consistent with the westerly displacement of midlatitude sulfur deposition flux changes in Fig. 10a with the stratosphere-troposphere sulfur downward fluxes of Fig. 13a.

As summarized in Fig. 3, the latitudinal distribution of sulfur deposition is regulated by the cross-tropopause downward fluxes due to both large-scale STE in the lower branch of the Brewer-Dobson circulation and by gravitational settling of the aerosol particles. The latter may be significantly modulated by the changing aerosol size distribution during different QBO phases, mainly in the tropical region (see Figs. 4 and 7). The former is also modulated by the QBO, as discussed and summarized in Fig. 4 and proved in Figs. 5-6 for both ULAQ-CCM and GEOS-Chem, with the net effect presented in Fig. 8 for the ULAQ-CCM.

The QBO's important role in modulating the poleward isentropic transport of sulfate from the tropical pipe reservoir (and consequently the extratropical stratosphere-troposphere downward flux of sulfur) can be clearly highlighted by showing in Fig. 13b, c the equivalent of Fig. 13a but in terms of QBO E-W shear anomalies of the cross-tropopause sulfur fluxes. Under an $\mathrm{E}$ shear the tropical confinement is increased, resulting in both a reduction in the lowerstratospheric isentropic transport toward the midlatitudes and an increase in tropical particle size because of the larger amount of sulfate mass concentration in the tropical pipe. Figure $13 \mathrm{~b}$ shows that the combination of these two factors modifies the cross-tropopause sulfur fluxes between $\mathrm{E}$ shear and $\mathrm{W}$ shear periods of the QBO, by increasing the downward flux in the tropics (for the larger aerosol settling ve- 


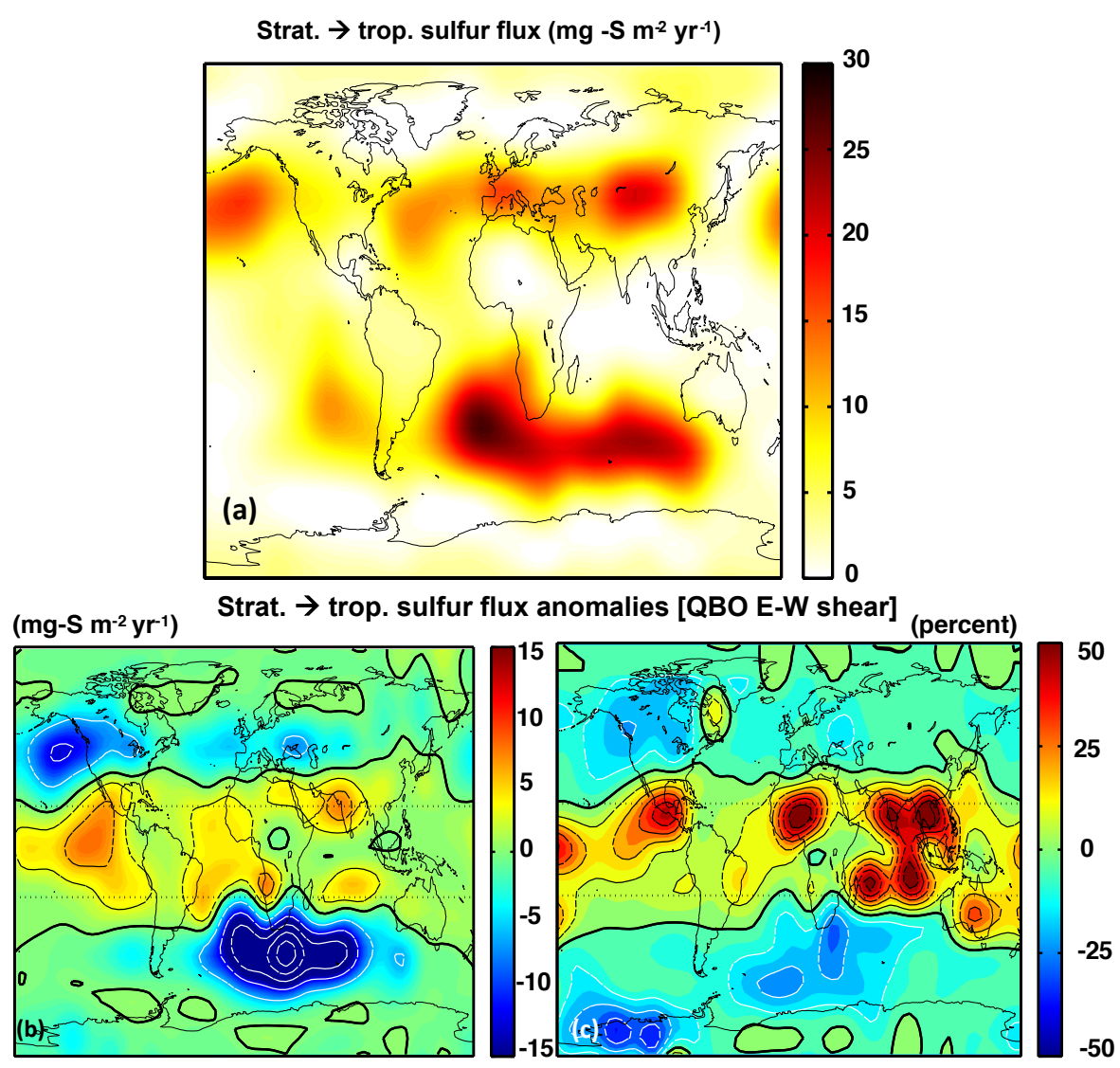

Figure 13. (a) Downward cross-tropopause sulfur flux changes (G4-Base) in ULAQ-CCM, as a function of latitude and longitude and averaged over the years 2030-2039 ( $\left.\mathrm{mg} \mathrm{S} \mathrm{m}^{-2} \mathrm{yr}^{-1}\right)$. Panels (b, c) as in (a) but showing differences between years with QBO easterly shear and years with QBO westerly shear; (b) shows the difference is in absolute units $\left(\mathrm{mg} \mathrm{S} \mathrm{m}^{-2} \mathrm{yr}^{-1}\right)$, whereas (c) shows the difference in percent of the decadal averaged flux changes presented in (a). Positive and negative anomalies are separated by the thick black curve (zero contour line); thin black/white curves show positive/negative contours with a step of $5 \mathrm{mg} \mathrm{S} \mathrm{m}^{-2} \mathrm{yr}^{-1}$ in (b) and $10 \%$ in (c); dotted lines highlight the subtropical barriers at $25^{\circ} \mathrm{N}$ and $25^{\circ} \mathrm{S}$. Integrated S-flux anomalies (QBO E-W shear) are as follows: tropics, $+0.61 \mathrm{Tg} \mathrm{S}$ yr ${ }^{-1}$ $(+42 \%) ; \mathrm{NH},-0.51 \mathrm{Tg} \mathrm{S} \mathrm{yr}^{-1}(-31 \%) ; \mathrm{SH},-0.35 \mathrm{Tg} \mathrm{S} \mathrm{yr}^{-1}$ (-39\%); global, $-0.25 \mathrm{Tg} \mathrm{S} \mathrm{yr}^{-1}(-6 \%)$.

locities) and decreasing it in the extratropics due to reduced poleward isentropic transport. This is further highlighted in Fig. $13 \mathrm{c}$ where the differences are shown in percent of the decadal average presented in Fig. 13a. The integrated positive tropical difference $(+42 \%)$ is larger with respect to each of the integrated negative extratropical differences $(-31$ in the $\mathrm{NH}$ and $-39 \%$ in the $\mathrm{SH})$. The net $\mathrm{E}-\mathrm{W}$ globally integrated flux anomaly, however, is negative $\left(-0.25 \mathrm{Tg} \mathrm{S} \mathrm{yr}^{-1}\right.$, i.e., $-6 \%)$, consistent with the stratospheric sulfate lifetime oscillations shown in Fig. 5.

The QBO E-W anomalies of cross-tropopause fluxes discussed above directly translate into surface deposition fluxes, as shown in Fig. 14. If we isolate those years in our numerical simulation with a dominant $\mathrm{E}$ shear of mean zonal winds and calculate the average S-deposition changes due to SG only during these years, we obtain the results summarized in Fig. 14 for the three latitudinal bands identified in Fig. 13 (tropics and the two extratropical regions). Signifi- cant anomalies of the integrated S-deposition flux changes are found with respect to the decadal average including both $\mathrm{E}$ and $\mathrm{W}$ wind shears, as in Figs. 9 and 10. The extratropical $\mathrm{S}$ deposition is found to decrease by up to $35.3 \%$ under $\mathrm{E}$ shear conditions in the Southern Hemisphere and by $16 \%$ as an average over both hemispheres. This is the direct consequence of the enhanced tropical confinement of SG aerosols under easterly wind shear, with decreasing isentropic poleward transport of sulfate. At the same time, the increasing aerosol size in the tropics (see Figs. 4 and 7) produces a larger cross-tropopause sedimentation flux and finally an increase in the tropical S-deposition change by $16.5 \%$ in our calculations.

Other than simply discriminating between the two QBO regimes, these results also show what changes in regional deposition one might expect in the case of an injection large enough to lock the QBO into a permanent $\mathrm{E}$ shear (Aquila et al., 2014). Although possible feedbacks of the QBO mod- 


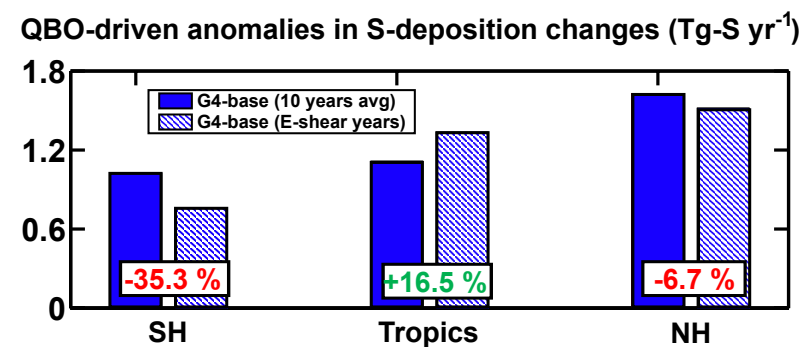

Figure 14. QBO-driven anomalies of S-deposition changes $\left(\mathrm{Tg} \mathrm{S} \mathrm{yr}^{-1}\right)$ in the tropical region $\left(25^{\circ} \mathrm{S}-25^{\circ} \mathrm{N}\right)$ and in the two extratropical regions, i.e., $90-25^{\circ} \mathrm{S}$ and $25-90^{\circ} \mathrm{N}$. The colored blue bars represent the S-deposition changes in the ULAQ-CCM averaged over the full decade 2030-2039. The striped blue bars represent the S-deposition changes calculated only under E shear condition. The numbers in the boxes show the percent changes in the S-deposition changes due to SG under E shear conditions with respect to the one calculated over the full decade, i.e., under both QBO regimes.

ifications to the aerosol microphysics (see Fig. 4) cannot be present in our model, if we average the $\mathrm{S}$ deposition only for years with a QBO E shear, this can be seen as a proxy of the actual S-deposition changes under a modified QBO regime with permanent locking into the E shear. This type of average may allow us to estimate the possible latitudinal distribution of the S-deposition changes in a SG scenario with a larger sulfur injection when the results are scaled accordingly.

\section{Conclusions}

The main goal of geoengineering is to reduce our planet surface warming, bound to happen if the amount of GHGs is not reduced via cuts in anthropogenic emissions (IPCC, 2013). In the case of SG, the main effect of cooling the planet could surely be achieved to some extent if the sulfate was actually injected into the tropical stratosphere, and we are assured of this both by looking at explosive volcanic eruptions and their effect on climate and by many results from the GeoMIP project, which come from a vast array of simulations from independent models (Kravitz et al., 2012; Visioni et al., 2017a). However, in terms of possible side effects, there is much still left to study and understand. In this study we focused on the SG impact on the surface deposition of sulfur in the case of an injection of $8 \mathrm{Tg} \mathrm{SO}_{2} \mathrm{yr}^{-1}$ simulated in two globalscale models: ULAQ-CCM and GEOS-Chem. Results from these simulations tell us that the stratospheric $\mathrm{SO}_{4}$ lifetime is highly correlated with the QBO phase (as already found in Pitari et al., 2016b, for explosive volcanic eruptions).

When the westerly phase is localized in the lower stratosphere (i.e., with an $\mathrm{E}$ shear of the equatorial mean zonal winds), the stratospheric $\mathrm{SO}_{4}$ lifetime is found to increase in the ULAQ-CCM by up to 4 months, with respect to the lifetime under a QBO easterly phase localized in the lower stratosphere (i.e., with a $\mathrm{W}$ shear of the equatorial mean zonal winds). This happens for two reasons: with an E shear, the horizontal isentropic transport of sulfate out of the tropical pipe is slower and the tropical upwelling is enhanced at all vertical layers (Trepte and Hitchman, 1992), thus allowing for a longer stratospheric residence time of the aerosols. This is the net result of two competing effects: less extratropical stratosphere-troposphere exchange is allowed during the $\mathrm{E}$ wind shear, and this overcompensates for an increasing tropical sedimentation of the sulfate particles, which may grow larger with an enhanced sulfur confinement in the tropical pipe.

A limitation of this study is the use of an assimilated or nudged QBO for both GEOS-Chem and ULAQ-CCM. This means that changes in QBO amplitude and periodicity due to aerosol radiative effects connected with $\mathrm{SG}$ conditions cannot be seen, as evidenced and discussed in Aquila et al. (2014), Niemeier and Timmreck (2015), and Niemeier and Schmidt (2017). On the one hand, this does not allow us to draw any broad conclusions regarding the final effect that the mutual interactions of aerosol size distribution, heating rate changes and QBO have on each other (the complex "balance" shown in Fig. 4). On the other hand, constraining some of the degrees of freedom does allow us to answer some compelling scientific questions regarding the uncertainties of sulfate geoengineering (MacMartin et al., 2016).

The consistency of results from the two models used in this study suggests, with a certain degree of confidence, that the $\mathrm{E}$ wind shear (i.e., QBO W phase in the lower equatorial stratosphere) is more favorable for producing a longer stratospheric lifetime of SG aerosols. However, when the aerosol size distribution is explicitly calculated online with the inclusion of the most important microphysical processes, the QBO modulation of the particle effective radius (see discussion of Fig. 7) implies that the largest surface cooling is achieved in the least favorable conditions in terms of stratospheric sulfate mass accumulation, that is with $\mathrm{W}$ wind shear (i.e., QBO E phase in the lower equatorial stratosphere). Niemeier and Timmreck (2015) and later Niemeier and Schmidt (2017) have already pointed out that larger injections tend to be less efficient in terms of radiative forcing. Our results can add to this the observation that, since injections under an $\mathrm{E}$ shear produce a decreased scattering (and forcing) efficiency, the most favorable SG scenario would be one that tends to prolong the E shear as little as possible. For instance, taking as an example the results shown in Aquila et al. (2014), we can suppose that the $2.5 \mathrm{Tg} \mathrm{S} \mathrm{yr}^{-1}$ injection scenario would have been more favorable in terms of radiative forcing, with respect to the (E shear locked) $5 \mathrm{Tg} \mathrm{S} \mathrm{yr}^{-1}$ scenario, had those simulations had an interactive aerosol microphysics.

Regarding surface deposition, in agreement with Kravitz et al. (2009) with an injection of $2.5 \mathrm{Tg} \mathrm{S} \mathrm{yr}^{-1}$, we found for that sulfur deposition changes are never above $15 \%$ of the Base scenario both ULAQ-CCM and GEOS-Chem, and that over continents they are on average around $5 \%$ 
for either model. However, when looking more in depth, a large interhemispheric difference is present $3.8 \%$ for the Northern Hemisphere against $10.3 \%$ for the Southern Hemisphere), and the same differences can be seen when looking at single areas, such as those where very little background deposition is present: Oceania and South America, with $8.8 \pm 0.7\left(0.27 \pm 0.02 \mathrm{Tg} \mathrm{S} \mathrm{yr}^{-1}\right)$ and $9.0 \pm 1.4 \%$ $\left(0.28 \pm 0.04 \mathrm{Tg} \mathrm{Syr}^{-1}\right)$ respectively, and Antarctica, with $7.7 \pm 0.7 \%\left(0.02 \pm 0.01 \mathrm{Tg} \mathrm{S} \mathrm{yr}^{-1}\right)$, where the uncertainties refer to the interannual S-deposition variability due to the QBO. While in those areas both models agree on the magnitude of the changes, in some other areas, such as the Arctic Ocean $\left(0.010 \pm 0.003 \mathrm{Tg} \mathrm{Syr}^{-1}\right.$ in GEOSChem against $0.03 \pm 0.01 \mathrm{TgS} \mathrm{yr}^{-1}$ in ULAQ-CCM) or Africa $\left(0.44 \pm 0.07 \mathrm{Tg} \mathrm{S} \mathrm{yr}^{-1}\right.$ against $0.08 \pm 0.05 \mathrm{Tg} \mathrm{S} \mathrm{yr}^{-1}$ in GEOS-Chem and ULAQ-CCM, respectively), the differences between models are large and the results do not allow a definitive answer. Regarding polar regions, especially in the $\mathrm{NH}$ where the two models differ significantly, ULAQ-CCM values seem to be more in line with retrieved values from ice cores after the Tambora eruption (at least indirectly, via a linear emission scaling, and then only in a first approximation).

Furthermore, these deposition results could be scaled down when considering stratospheric sulfur injections lower than $4 \mathrm{Tg} \mathrm{Syr}^{-1}$. This might happen, for instance, in the following cases: (1) a less aggressive approach is considered to achieve different temperature reduction targets (Tilmes et al., 2016); (2) we consider different scenarios over which to apply the proposed solar radiation management (MacMartin et al., 2014); or (3) the sum all of indirect radiative effects of SG ends up producing a negative forcing that, by going the same way as the direct solar radiation scattering, would allow for a smaller injection to reach a certain target (Visioni et al., 2017a). As an example, considering the $2.5 \mathrm{Tg} \mathrm{S} \mathrm{yr}^{-1}$ injection proposed in the GeoMIP G4 experiment (Kravitz et al., 2011), the resulting deposition would be lowered down to $2.3 \%$ in the $\mathrm{NH}$ and $6.4 \%$ in the SH. Looking at some of our regional results scaled per unit $\mathrm{Tg} \mathrm{S} \mathrm{yr}{ }^{-1}$ injection and comparing them with the baseline deposition fluxes reported in Vet et al. (2014), we conclude that South America would receive $0.06 \mathrm{Tg} \mathrm{S} \mathrm{yr}^{-1}$ more deposition (against 3.2 $\mathrm{TgS} \mathrm{yr}^{-1}$ of baseline $\mathrm{S}$ deposition, i.e., $2 \%$ per injected $\mathrm{Tg} \mathrm{S} \mathrm{yr}^{-1}$ ), the Indian Ocean would receive an additional $0.12 \mathrm{Tg} \mathrm{S} \mathrm{yr}^{-1}$ (against $7.1 \mathrm{Tg} \mathrm{S} \mathrm{yr}^{-1}$, i.e., $1.7 \%$ per injected $\mathrm{Tg} \mathrm{Syr}^{-1}$ ), and Europe and North America would receive an additional 0.032 and $0.078 \mathrm{Tg} \mathrm{S} \mathrm{yr}^{-1}$, respectively (against 12.1 and $10.5 \mathrm{Tg} \mathrm{S} \mathrm{yr}^{-1}$, respectively, i.e., 0.26 and $0.74 \%$ per injected $\mathrm{TgS}_{\mathrm{yr}}{ }^{-1}$ ). However, it should be noted that our results and the previous discussion only focus on sulfate geoengineering considering a stratospheric injection of $\mathrm{SO}_{2}$, with the subsequent coagulation process previously discussed (gas condensation, coagulation, sedimentation). It might be possible to obtain different results in terms of the size distribution of the sulfate particles if a different injection strategy is designed, for instance using sulfuric acid or sulfur trioxide (Pierce et al., 2010; Keith and MacMartin, 2015), thus producing different results in terms of cross-tropopause fluxes and finally in terms of surface deposition.

Focusing on the latitudinal distribution of $\mathrm{S}$ deposition, we suggest a potential significant impact due to the SG feedback on the QBO. Considering scenarios with larger injections that end up locking the lower-stratospheric mean zonal winds in a westerly phase (see Aquila et al., 2014; Niemeier and Schmidt, 2017), the results presented in Figs. 13b, c14 point to an upper-limit increase in the tropical SG deposition change by $16.5 \%$ with respect to a time-averaged value with an externally nudged QBO. The other evidence is a corresponding upper-limit decrease in the extratropical deposition by $16 \%$. However, recent investigations by Tilmes et al. (2017) and Richter et al. (2017) show that the SG impact on the baseline QBO regimes would be significantly decreased in the case of a sulfur injection located off the equator and closer to the subtropics, using injections from 6 to $12 \mathrm{Tg} \mathrm{SO}_{2} \mathrm{yr}^{-1}$.

As already noted by Kravitz et al. (2009), deposition results do not take into account local changes in precipitation patterns that might occur over specific areas of the globe or the response of single ecosystems, but they might give some indications towards which areas might be affected more. In this way, the results obtained in this study should not be considered an endorsement of sulfate geoengineering, and more results on this subject are needed, especially regarding the sulfur deposition increase over Arctic and Antarctic polar regions. We also believe that the need for further studies regarding SG is highlighted (as shown also in this paper) by the complexity and nonlinear interaction among some processes that together regulate the latitude-longitude distribution of sulfur deposition changes, namely aerosol microphysics and heating rates, QBO, forcing efficiency, and circulation changes.

Data availability. Data from model simulations are available from the corresponding author.

\section{The Supplement related to this article is available online at https://doi.org/10.5194/acp-18-2787-2018-supplement.}

Competing interests. The authors declare that they have no conflict of interest.

Special issue statement. This article is part of the special issue "The Geoengineering Model Intercomparison Project (GeoMIP): Simulations of solar radiation reduction methods (ACP/GMD interjournal SI)". It is not associated with a conference. 
Acknowledgements. Paolo Tuccella is beneficiary of an AXA Research Fund postdoctoral grant.

Edited by: Ben Kravitz

Reviewed by: two anonymous referees

\section{References}

Amos, H. M., Jacob, D. J., Holmes, C. D., Fisher, J. A., Wang, Q., Yantosca, R. M., Corbitt, E. S., Galarneau, E., Rutter, A. P., Gustin, M. S., Steffen, A., Schauer, J. J., Graydon, J. A., Louis, V. L. St., Talbot, R. W., Edgerton, E. S., Zhang, Y., and Sunderland, E. M.: Gas-particle partitioning of atmospheric $\mathrm{Hg}(\mathrm{II})$ and its effect on global mercury deposition, Atmos. Chem. Phys., 12, 591-603, https://doi.org/10.5194/acp-12-591-2012, 2012.

Aquila, V., Garfinkel, C., Newman, P., Oman, L., and Waugh, D.: Modifications of the quasi-biennial oscillation by a geoengineering perturbation of the stratospheric aerosol layer, Geophys. Res. Lett., 41, 1738-1744, 2014.

Bey, I., Jacob, D. J., Yantosca, R. M., Logan, J. A., Field, B. D., Fiore, A. M., Li, Q., Liu, H. Y., Mickley, L. J., and Schultz, M. G.: Global modeling of tropospheric chemistry with assimilated meteorology: Model description and evaluation, J. Geophys. Res.-Atmos., 106, 23073-23095, https://doi.org/10.1029/2001JD000807, 2001.

Bian, H. and Prather, M. J.: Fast-J2: Accurate Simulation of Stratospheric Photolysis in Global Chemical Models, J. Atmos. Chem., 41, 281-296, https://doi.org/10.1023/A:1014980619462, 2002.

Budyko, M. I.: The Climate of the Future, American Geophysical Union, 197-245, https://doi.org/10.1002/9781118665251.ch7, 1974.

Butchart, N., Cionni, I., Eyring, V., Shepherd, T. G., Waugh, D. W., Akiyoshi, H., Austin, J., Brühl, C., Chipperfield, M. P., Cordero, E., Dameris, M., Deckert, R., Dhomse, S., Frith, S. M., Garcia, R. R., Gettelman, A., Giorgetta, M. A., Kinnison, D. E., Li, F., Mancini, E., McLandress, C., Pawson, S., Pitari, G., Plummer, D. A., Rozanov, E., Sassi, F., Scinocca, J. F., Shibata, K., Steil, B., and Tian, W.: Chemistry-Climate Model Simulations of Twenty-First Century Stratospheric Climate and Circulation Changes, J. Climate, 23, 5349-5374, https://doi.org/10.1175/2010JCLI3404.1, 2010.

Chou, M. D., Suarez, M. J., Liang, X. Z., and Yan, M. M. H.: A thermal infrared radiation parameterization for atmospheric studies, Tech. Rep. TM-2001-104606, NASA, NASA Goddard Space Flight Cent., Greenbelt, MD, 2001.

Clegg, S. M. and Abbatt, J. P. D.: Oxidation of $\mathrm{SO}_{2}$ by $\mathrm{H}_{2} \mathrm{O}_{2}$ on ice surfaces at $228 \mathrm{~K}$ : a sink for $\mathrm{SO}_{2}$ in ice clouds, Atmos. Chem. Phys., 1, 73-78, https://doi.org/10.5194/acp-1-73-2001, 2001.

Crutzen, P. J.: Albedo Enhancement by Stratospheric Sulfur Injections: A Contribution to Resolve a Policy Dilemma?, Climatic Change, 77, 211-220, https://doi.org/10.1007/s10584-006-9101y, 2006.

Eastham, S. D., Weisenstein, D. K., and Barrett, S. R.: Development and evaluation of the unified troposphericstratospheric chemistry extension (UCX) for the global chemistry-transport model GEOS-Chem, Atmos. Environ., 89, 52-63, https://doi.org/10.1016/j.atmosenv.2014.02.001, 2014.
Eyring, V., Butchart, N., Waugh, D. W., Akiyoshi, H., Austin, J., Bekki, S., Bodeker, G. E., Boville, B. A., Bruhl, C., Chipperfield, M. P., Cordero, E., Dameris, M., Deushi, M., Fioletov, V. E., Frith, S. M., Garcia, R. R., Gettelman, A., Giorgetta, M. A., Grewe, V., Jourdain, L., Kinnison, D. E., Mancini, E., Manzini, E., Marchand, M., Marsh, D. R., Nagashima, T., Newman, P. A., Nielsen, J. E., Pawson, S., Pitari, G., Plummer, D. A., Rozanov, E., Schraner, M., Shepherd, T. G., Shibata, K., Stolarski, R. S., Struthers, H., Tian, W., and Yoshiki, M.: Assessment of temperature, trace species, and ozone in chemistry-climate model simulations of the recent past, J. Geophys. Res.-Atmos., 111, D22308, https://doi.org/10.1029/2006JD007327, 2006.

Eyring, V., Arblaster, J. M., Cionni, I., Sedlacek, J., Perlwitz, J., Young, P. J., Bekki, S., Bergmann, D., Cameron-Smith, P., Collins, W. J., Faluvegi, G., Gottschaldt, K.-D., Horowitz, L. W., Kinnison, D. E., Lamarque, J.-F., Marsh, D. R., Saint-Martin, D., Shindell, D. T., Sudo, K., Szopa, S., and Watanabe, S.: Long-term ozone changes and associated climate impacts in CMIP5 simulations, J. Geophys. Res.-Atmos., 118, 5029-5060, https://doi.org/10.1002/jgrd.50316, 2013.

Feichter, J., Kjellstram, E., Rodhe, H., Dentener, F., Lelieveldi, J., and Roelofs, G.-J.: Simulation of the tropospheric sulfur cycle in a global climate model, Atmos. Environ., 30, 1693-1707, https://doi.org/10.1016/1352-2310(95)00394-0, 1996.

Fisher, J. A., Jacob, D. J., Wang, Q., Bahreini, R., Carouge, C. C., Cubison, M. J., Dibb, J. E., Diehl, T., Jimenez, J. L., Leibensperger, E. M., Lu, Z., Meinders, M. B., Pye, H. O., Quinn, P. K., Sharma, S., Streets, D. G., van Donkelaar, A., and Yantosca, R. M.: Sources, distribution, and acidity of sulfate-ammonium aerosol in the Arctic in winter-spring, Atmos. Environ., 45, 7301-7318, https://doi.org/10.1016/j.atmosenv.2011.08.030, 2011.

Gao, C., Oman, L., Robock, A., and Stenchikov, G. L.: Atmospheric volcanic loading derived from bipolar ice cores: Accounting for the spatial distribution of volcanic deposition, J. Geophys. Res.Atmos., 112, D09109, https://doi.org/10.1029/2006JD007461, 2007.

Gettelman, A., Hegglin, M. I., Son, S.-W., Kim, J., Fujiwara, M., Birner, T., Kremser, S., Rex, M., Anel, J. A., Akiyoshi, H., Austin, J., Bekki, S., Braesike, P., Bruhl, C., Butchart, N., Chipperfield, M., Dameris, M., Dhomse, S., Garny, H., Hardiman, S. C., Jockel, P., Kinnison, D. E., Lamarque, J. F., Mancini, E., Marchand, M., Michou, M., Morgenstern, O., Pawson, S., Pitari, G., Plummer, D., Pyle, J. A., Rozanov, E., Scinocca, J., Shepherd, T. G., Shibata, K., Smale, D., Teyssedre, H., and Tian, W.: Multimodel assessment of the upper troposphere and lower stratosphere: Tropics and global trends, J. Geophys. Res.-Atmos., 115, D00M08, https://doi.org/10.1029/2009JD013638, 2010.

Grainger, R. G., Lambert, A., Rodgers, C. D., Taylor, F. W., and Deshler, T.: Stratospheric aerosol effective radius, surface area and volume estimated from infrared measurements, J. Geophys. Res.-Atmos., 100, 16507-16518, https://doi.org/10.1029/95JD00988, 1995.

Grant, W. B., Fishman, J., Browell, E. V., Brackett, V. G., Nganga, D., Minga, A., Cros, B., Veiga, R. E., Butler, C. F., Fenn, M. A., and Nowicki, G. D.: Observations of reduced ozone concentrations in the tropical stratosphere after the eruption of Mt. Pinatubo, Geophys. Res. Lett., 19, 1109-1112, https://doi.org/10.1029/92GL01153, 1992. 
Hegglin, M. I., Gettelman, A., Hoor, P., Krichevsky, R., Manney, G. L., Pan, L. L., Son, S.-W., Stiller, G., Tilmes, S., Walker, K. A., Eyring, V., Shepherd, T. G., Waugh, D., Akiyoshi, H., Anel, J. A., Austin, J., Baumgaertner, A., Bekki, S., Braesicke, P., Bruhl, C., Butchart, N., Chipperfield, M. P., Dameris, M., Dhomse, S., Frith, S., Garny, H., Hardiman, S. C., Jockel, P., Kinnison, D. E., Lamarque, J. F., Mancini, E., Michou, M., Morgenstern, O., Nakamura, T., Olivie, D., Pawson, S., Pitari, G., Plummer, D. A., Pyle, J. A., Rozanov, E., Scinocca, J. F., Shibata, K., Smale, D., Teyssedre, H., Tian, W., and Yamashita, Y.: Multimodel assessment of the upper troposphere and lower stratosphere: Extra-tropics, J. Geophys. Res.-Atmos., 115, D00M09, https://doi.org/10.1029/2010JD013884, 2010.

Holton, J. R. and Tan, H.-C.: The Influence of the Equatorial Quasi-Biennial Oscillation on the Global Circulation at $50 \mathrm{mb}$, J. Atmos. Sci., 37, 2200-2208, https://doi.org/10.1175/15200469(1980)037<2200:TIOTEQ>2.0.CO;2, 1980.

Hommel, R., Timmreck, C., Giorgetta, M. A., and Graf, H. F.: Quasi-biennial oscillation of the tropical stratospheric aerosol layer, Atmos. Chem. Phys., 15, 5557-5584, https://doi.org/10.5194/acp-15-5557-2015, 2015.

Hsu, J., Prather, M., and Wild, O.: Diagnosing the stratosphere-totroposphere flux of ozone in a chemistry transport model, J. Geophys. Res.-Atmos., 110, https://doi.org/10.1029/2005JD006045, 2005.

IPCC: Climate Change 2013: The Physical Science Basis, Contribution of Working Group I to the Fifth Assessment Report of the Intergovernmental Panel on Climate Change, Cambridge Univ. Press, Cambridge, 2013.

Keith, D. W. and MacMartin, D. G.: A temporary, moderate and responsive scenario for solar geoengineering, Nature Climate Change, 5, 201-206, https://doi.org/10.1038/nclimate2493, 2015.

Kirchner, I., Stenchikov, G. L., Graf, H.-F., Robock, A., and Antuna, J. C.: Climate model simulation of winter warming and summer cooling following the 1991 Mount Pinatubo volcanic eruption, J. Geophys. Res.-Atmos., 104, 19039-19055, https://doi.org/10.1029/1999JD900213, 1999.

Kleinschmitt, C., Boucher, O., and Platt, U.: Sensitivity of the radiative forcing by stratospheric sulfur geoengineering to the amount and strategy of the $\mathrm{SO}_{2}$ injection studied with the LMDZ-S3A model, Atmos. Chem. Phys. Discuss., https://doi.org/10.5194/acp-2017-722, in review, 2017.

Kravitz, B., Robock, A., Oman, L., Stenchikov, G., and Marquardt, A. B.: Sulfuric acid deposition from stratospheric geoengineering with sulfate aerosols, J. Geophys. Res.-Atmos., 114, D14109, https://doi.org/10.1029/2009JD011918, 2009.

Kravitz, B., Robock, A., Oman, L., Stenchikov, G., and Marquardt, A. B.: Correction to "Sulfuric acid deposition from stratospheric geoengineering with sulfate aerosols", J. Geophys. Res.-Atmos., 115, D16119, https://doi.org/10.1029/2010JD014579, 2010.

Kravitz, B., Robock, A., Boucher, O., Schmidt, H., Taylor, K. E., Stenchikov, G., and Schulz, M.: The Geoengineering Model Intercomparison Project (GeoMIP), Atmos. Sci. Lett., 12, 162167, https://doi.org/10.1002/as1.316, 2011.

Kravitz, B., Robock, A., and Haywood, J. M.: Progress in climate model simulations of geoengineering, EOS Transactions American Geophysical Union, 93, 340-340, https://doi.org/10.1029/2012EO350009, 2012.
Labitzke, K. and McCormick, M. P.: Stratospheric temperature increases due to Pinatubo aerosols, Geophys. Res. Lett., 19, 207210, https://doi.org/10.1029/91GL02940, 1992.

Lamarque, J.-F., Bond, T. C., Eyring, V., Granier, C., Heil, A., Klimont, Z., Lee, D., Liousse, C., Mieville, A., Owen, B., Schultz, M. G., Shindell, D., Smith, S. J., Stehfest, E., Van Aardenne, J., Cooper, O. R., Kainuma, M., Mahowald, N., McConnell, J. R., Naik, V., Riahi, K., and van Vuuren, D. P.: Historical (1850-2000) gridded anthropogenic and biomass burning emissions of reactive gases and aerosols: methodology and application, Atmos. Chem. Phys., 10, 7017-7039, https://doi.org/10.5194/acp-10-7017-2010, 2010.

Lamarque, J.-F., Dentener, F., McConnell, J., Ro, C.-U., Shaw, M., Vet, R., Bergmann, D., Cameron-Smith, P., Dalsoren, S., Doherty, R., Faluvegi, G., Ghan, S. J., Josse, B., Lee, Y. H., MacKenzie, I. A., Plummer, D., Shindell, D. T., Skeie, R. B., Stevenson, D. S., Strode, S., Zeng, G., Curran, M., Dahl-Jensen, D., Das, S., Fritzsche, D., and Nolan, M.: Multi-model mean nitrogen and sulfur deposition from the Atmospheric Chemistry and Climate Model Intercomparison Project (ACCMIP): evaluation of historical and projected future changes, Atmos. Chem. Phys., 13, 7997-8018, https://doi.org/10.5194/acp-137997-2013, 2013.

Lambert, A., Grainger, R. G., Remedios, J. J., Rodgers, C. D., Corney, M., and Taylor, F. W.: Measurements of the evolution of the Mt. Pinatubo aerosol cloud by ISAMS, Geophys. Res. Lett., 20, 1287-1290, https://doi.org/10.1029/93GL00827, 1993.

Lin, J.-T. and McElroy, M. B.: Impacts of boundary layer mixing on pollutant vertical profiles in the lower troposphere: Implications to satellite remote sensing, Atmos. Environ., 44, 17261739, https://doi.org/10.1016/j.atmosenv.2010.02.009, 2010.

Lin, S.-J. and Rood, R. B.: Multidimensional Flux-Form Semi-Lagrangian Transport Schemes, Mon. Weather Rev., 124, 2046-2070, https://doi.org/10.1175/15200493(1996)124<2046:MFFSLT>2.0.CO;2, 1996.

Liu, H., Jacob, D. J., Bey, I., and Yantosca, R. M.: Constraints from $210 \mathrm{~Pb}$ and $7 \mathrm{Be}$ on wet deposition and transport in a global threedimensional chemical tracer model driven by assimilated meteorological fields, J. Geophys. Res.-Atmos., 106, 12109-12128, https://doi.org/10.1029/2000JD900839, 2001.

Long, C. S. and Stowe, L. L.: using the NOAA/AVHRR to study stratospheric aerosol optical thicknesses following the Mt. Pinatubo Eruption, Geophys. Res. Lett., 21, 2215-2218, https://doi.org/10.1029/94GL01322, 1994.

MacMartin, D. G., Caldeira, K., and Keith, D. W.: Solar geoengineering to limit the rate of temperature change, Philos. T. R. Soc. Lond., 372, https://doi.org/10.1098/rsta.2014.0134, 2014.

MacMartin, D. G., Kravitz, B., Long, J. C. S., and Rasch, P. J.: Geoengineering with stratospheric aerosols: What do we not know after a decade of research?, Earth's Future, 4, 543-548, https://doi.org/10.1002/2016EF000418, 2016.

Marshall, L., Schmidt, A., Toohey, M., Carslaw, K. S., Mann, G. W., Sigl, M., Khodri, M., Timmreck, C., Zanchettin, D., Ball, W. T., Bekki, S., Brooke, J. S. A., Dhomse, S., Johnson, C., Lamarque, J.-F., LeGrande, A. N., Mills, M. J., Niemeier, U., Pope, J. O., Poulain, V., Robock, A., Rozanov, E., Stenke, A., Sukhodolov, T., Tilmes, S., Tsigaridis, K., and Tummon, F.: Multi-model comparison of the volcanic sulfate deposition from the 1815 
eruption of Mt. Tambora, Atmos. Chem. Phys., 18, 2307-2328, https://doi.org/10.5194/acp-18-2307-2018, 2018.

McCormick, M. P. and Veiga, R. E.: SAGE II measurements of early Pinatubo aerosols, Geophys. Res. Lett., 19, 155-158, https://doi.org/10.1029/91GL02790, 1992.

Morgenstern, O., Giorgetta, M. A., Shibata, K., Eyring, V., Waugh, D. W., Shepherd, T. G., Akiyoshi, H., Austin, J., Baumgaertner, A. J. G., Bekki, S., Braesicke, P., Bruhl, C., Chipperfield, M. P., Cugnet, D., Dameris, M., Dhomse, S., Frith, S. M., Garny, H., Gettelman, A., Hardiman, S. C., Hegglin, M. I., Jockel, P., Kinnison, D. E., Lamarque, J.-F., Mancini, E., Manzini, E., Marchand, M., Michou, M., Nakamura, T., Nielsen, J. E., Olivie, D., Pitari, G., Plummer, D. A., Rozanov, E., Scinocca, J. F., Smale, D., Teyssedre, H., Toohey, M., Tian, W., and Yamashita, Y.: Review of the formulation of presentgeneration stratospheric chemistry-climate models and associated external forcings, J. Geophys. Res.-Atmos., 115, D00M02, https://doi.org/10.1029/2009JD013728, 2010.

Morgenstern, O., Hegglin, M. I., Rozanov, E., O’Connor, F. M., Abraham, N. L., Akiyoshi, H., Archibald, A. T., Bekki, S., Butchart, N., Chipperfield, M. P., Deushi, M., Dhomse, S. S., Garcia, R. R., Hardiman, S. C., Horowitz, L. W., Jöckel, P., Josse, B., Kinnison, D., Lin, M., Mancini, E., Manyin, M. E., Marchand, M., Marécal, V., Michou, M., Oman, L. D., Pitari, G., Plummer, D. A., Revell, L. E., Saint-Martin, D., Schofield, R., Stenke, A., Stone, K., Sudo, K., Tanaka, T. Y., Tilmes, S., Yamashita, Y., Yoshida, K., and Zeng, G.: Review of the global models used within phase 1 of the Chemistry-Climate Model Initiative (CCMI), Geosci. Model Dev., 10, 639-671, https://doi.org/10.5194/gmd-10-639-2017, 2017.

Muller, J.-F. and Brasseur, G.: IMAGES: A threedimensional chemical transport model of the global troposphere, J. Geophys. Res.-Atmos., 100, 16445-16490, https://doi.org/10.1029/94JD03254, 1995.

Niemeier, U. and Schmidt, H.: Changing transport processes in the stratosphere by radiative heating of sulfate aerosols, Atmos. Chem. Phys., 17, 14871-14886, https://doi.org/10.5194/acp-1714871-2017, 2017.

Niemeier, U. and Tilmes, S.: Sulfur injections for a cooler planet, Science, 357, 246-248, https://doi.org/10.1126/science.aan3317, 2017.

Niemeier, U. and Timmreck, C.: What is the limit of climate engineering by stratospheric injection of $\mathrm{SO}_{2}$ ?, Atmos. Chem. Phys., 15, 9129-9141, https://doi.org/10.5194/acp-159129-2015, 2015.

Park, R. J., Jacob, D. J., Chin, M., and Martin, R. V.: Sources of carbonaceous aerosols over the United States and implications for natural visibility, J. Geophys. Res.-Atmos., 108, 4355, https://doi.org/10.1029/2002JD003190, 2003.

Park, R. J., Jacob, D. J., Field, B. D., Yantosca, R. M., and Chin, M.: Natural and transboundary pollution influences on sulfate-nitrate-ammonium aerosols in the United States: Implications for policy, J. Geophys. Res.-Atmos., 109, D15204, https://doi.org/10.1029/2003JD004473, 2004.

Parrella, J. P., Jacob, D. J., Liang, Q., Zhang, Y., Mickley, L. J., Miller, B., Evans, M. J., Yang, X., Pyle, J. A., Theys, N., and Van Roozendael, M.: Tropospheric bromine chemistry: implications for present and pre-industrial ozone and mercury, At- mos. Chem. Phys., 12, 6723-6740, https://doi.org/10.5194/acp12-6723-2012, 2012.

Pierce, J. R., Weisenstein, D. K., Heckendorn, P., Peter, T., and Keith, D. W.: Efficient formation of stratospheric aerosol for climate engineering by emission of condensible vapor from aircraft, Geophys. Res. Lett., 37, L18805, https://doi.org/10.1029/2010GL043975, 2010.

Pitari, G.: A Numerical Study of the Possible Perturbation of Stratospheric Dynamics Due to Pinatubo Aerosols: Implications for Tracer Transport, J. Atmos. Sci., 50, 2443-2461, https://doi.org/10.1175/1520 0469(1993)050<2443:ANSOTP>2.0.CO;2, 1993.

Pitari, G., Mancini, E., Rizi, V., and Shindell, D. T.: Impact of Future Climate and Emission Changes on Stratospheric Aerosols and Ozone, J. Atmos. Sci., 59, 414-440, https://doi.org/10.1175/15200469(2002)059<0414:IOFCAE>2.0.CO;2, 2002.

Pitari, G., Aquila, V., Kravitz, B., Robock, A., Watanabe, S., Cionni, I., Luca, N. D., Genova, G. D., Mancini, E., and Tilmes, S.: Stratospheric ozone response to sulfate geoengineering: Results from the Geoengineering Model Intercomparison Project (GeoMIP), J. Geophys. Res.-Atmos., 119, 2629-2653, https://doi.org/10.1002/2013JD020566, 2014.

Pitari, G., Cionni, I., Di Genova, G., Visioni, D., Gandolfi, I., and Mancini, E.: Impact of Stratospheric Volcanic Aerosols on Ageof-Air and Transport of Long-Lived Species, Atmosphere, 122, 12557-12573, 2016a.

Pitari, G., Di Genova, G., Mancini, E., Visioni, D., Gandolfi, I., and Cionni, I.: Stratospheric Aerosols from Major Volcanic Eruptions: A Composition-Climate Model Study of the Aerosol Cloud Dispersal and e-folding Time, Atmosphere, 7, 79, https://doi.org/10.3390/atmos7060075, 2016b.

Pitari, G., Visioni, D., Mancini, E., Cionni, I., Di Genova, G., and Gandolfi, I.: Sulfate Aerosols from NonExplosive Volcanoes: Chemical-Radiative Effects in the Troposphere and Lower Stratosphere, Atmosphere, 85, https://doi.org/10.3390/atmos7070085 2016c.

Randles, C. A., Kinne, S., Myhre, G., Schulz, M., Stier, P., Fischer, J., Doppler, L., Highwood, E., Ryder, C., Harris, B., Huttunen, J., Ma, Y., Pinker, R. T., Mayer, B., Neubauer, D., Hitzenberger, R., Oreopoulos, L., Lee, D., Pitari, G., Di Genova, G., Quaas, J., Rose, F. G., Kato, S., Rumbold, S. T., Vardavas, I., Hatzianastassiou, N., Matsoukas, C., Yu, H., Zhang, F., Zhang, H., and $\mathrm{Lu}$, P.: Intercomparison of shortwave radiative transfer schemes in global aerosol modeling: results from the AeroCom Radiative Transfer Experiment, Atmos. Chem. Phys., 13, 2347-2379, https://doi.org/10.5194/acp-13-2347-2013, 2013.

Richter, J. H., Tilmes, S., Mills, M. J., Tribbia, J. J., Kravitz, B., MacMartin, D. G., Vitt, F., and Lamarque, J.-F.: Stratospheric Dynamical Response and Ozone Feedbacks in the Presence of SO2 Injections, J. Geophys. Res.-Atmos., 122, 2017JD026912, https://doi.org/10.1002/2017JD026912, 2017.

Robock, A., Kravitz, B., and Boucher, O.: Standardizing experiments in geoengineering, EOS Transactions American Geophysical Union, 92, 197-197, https://doi.org/10.1029/2011EO230008, 2011.

Sigl, M., Winstrup, M., McConnell, J. R., Welten, K. C., Plunkett, G., Ludlow, F., Buntgen, U., Caffee, M., Chellman, N., Dahl-Jensen, D., Fischer, H., Kipfstuhl, S., Kostick, C., Maselli, 
O. J., Mekhaldi, F., Mulvaney, R., Muscheler, R., Pasteris, D. R., Pilcher, J. R., Salzer, M., Schupbach, S., Steffensen, J. P., Vinther, B. M., and Woodruff, T. E.: Timing and climate forcing of volcanic eruptions for the past 2,500 years, Nature, 523, 543-549, https://doi.org/10.1038/nature14565, 2015.

Soden, B. J., Wetherald, R. T., Stenchikov, G. L., and Robock, A.: Global Cooling After the Eruption of Mount Pinatubo: A Test of Climate Feedback by Water Vapor, Science, 296, 727-730, https://doi.org/10.1126/science.296.5568.727, 2002.

Taylor, K. E., Stouffer, R. J., and Meehl, G. A.: An overview of CMIP5 and the experiment design, B. Am. Meteorol. Soc., 93, 83, https://doi.org/10.1175/BAMS-D-11-00094.1, 2012.

Tilmes, S., Muller, R., and Salawitch, R.: The Sensitivity of Polar Ozone Depletion to Proposed Geoengineering Schemes, Science, 320, 1201-1204, https://doi.org/10.1126/science.1153966, 2008.

Tilmes, S., Kinnison, D. E., Garcia, R. R., Salawitch, R., Canty, T., Lee-Taylor, J., Madronich, S., and Chance, K.: Impact of very short-lived halogens on stratospheric ozone abundance and UV radiation in a geo-engineered atmosphere, Atmos. Chem. Phys., 12, 10945-10955, https://doi.org/10.5194/acp-12-109452012, 2012.

Tilmes, S., Mills, M. J., Niemeier, U., Schmidt, H., Robock, A., Kravitz, B., Lamarque, J.-F., Pitari, G., and English, J. M.: A new Geoengineering Model Intercomparison Project (GeoMIP) experiment designed for climate and chemistry models, Geosci. Model Dev., 8, 43-49, https://doi.org/10.5194/gmd-8-43-2015, 2015.

Tilmes, S., Sanderson, B. M., and O’Neill, B. C.: Climate impacts of geoengineering in a delayed mitigation scenario, Geophys. Res. Lett., 43, 8222-8229, https://doi.org/10.1002/2016GL070122, 2016.

Tilmes, S., Richter, J. H., Mills, M. J., Kravitz, B., MacMartin, D. G., Vitt, F., Tribbia, J. J., and Lamarque, J.-F.: Sensitivity of Aerosol Distribution and Climate Response to Stratospheric SO2 Injection Locations, J. Geophys. Res.-Atmos., 122, 2017JD026888, https://doi.org/10.1002/2017JD026888, 2017.

Trepte, C. R. and Hitchman, M. H.: Tropical stratospheric circulation deduced from satellite aerosol data, Nature, 355, 626-628, https://doi.org/10.1038/355626a0, 1992.
Vet, R., Artz, R. S., Carou, S., Shaw, M., Ro, C.-U., Aas, W., Baker, A., Bowersox, V. C., Dentener, F., Galy-Lacaux, C., Hou, A., Pienaar, J. J., Gillett, R., Forti, M. C., Gromov, S., Hara, H., Khodzher, T., Mahowald, N. M., Nickovic, S., Rao, P., and Reid, N. W.: A global assessment of precipitation chemistry and deposition of sulfur, nitrogen, sea salt, base cations, organic acids, acidity and $\mathrm{pH}$, and phosphorus, Atmos. Environ., 93, 3-100, https://doi.org/10.1016/j.atmosenv.2013.10.060, 2014.

Visioni, D., Pitari, G., and Aquila, V.: Sulfate geoengineering: a review of the factors controlling the needed injection of sulfur dioxide, Atmos. Chem. Phys., 17, 3879-3889, https://doi.org/10.5194/acp-17-3879-2017, 2017a.

Visioni, D., Pitari, G., Aquila, V., Tilmes, S., Cionni, I., Di Genova, G., and Mancini, E.: Sulfate geoengineering impact on methane transport and lifetime: results from the Geoengineering Model Intercomparison Project (GeoMIP), Atmos. Chem. Phys., 17, 11209-11226, https://doi.org/10.5194/acp-17-112092017, 2017 b.

Wang, Y., Jacob, D. J., and Logan, J. A.: Global simulation of tropospheric O3-NOx-hydrocarbon chemistry: 1. Model formulation, J. Geophys. Res.-Atmos., 103, 10713-10725, https://doi.org/10.1029/98JD00158, 1998.

Wesely, M.: Parameterization of surface resistances to gaseous dry deposition in regional-scale numerical models, Atmos. Environ., 23, 1293-1304, https://doi.org/10.1016/0004-6981(89)90153-4, 1989.

Wu, S., Mickley, L. J., Jacob, D. J., Logan, J. A., Yantosca, R. M., and Rind, D.: Why are there large differences between models in global budgets of tropospheric ozone?, J. Geophys. Res.-Atmos., 112, D05302, https://doi.org/10.1029/2006JD007801, 2007.

Xia, L., Nowack, P. J., Tilmes, S., and Robock, A.: Impacts of stratospheric sulfate geoengineering on tropospheric ozone, Atmos. Chem. Phys., 17, 11913-11928, https://doi.org/10.5194/acp-17-11913-2017, 2017.

Zhang, L., Gong, S., Padro, J., and Barrie, L.: A size-segregated particle dry deposition scheme for an atmospheric aerosol module, Atmos. Environ., 35, 549-560, https://doi.org/10.1016/S13522310(00)00326-5, 2001. 